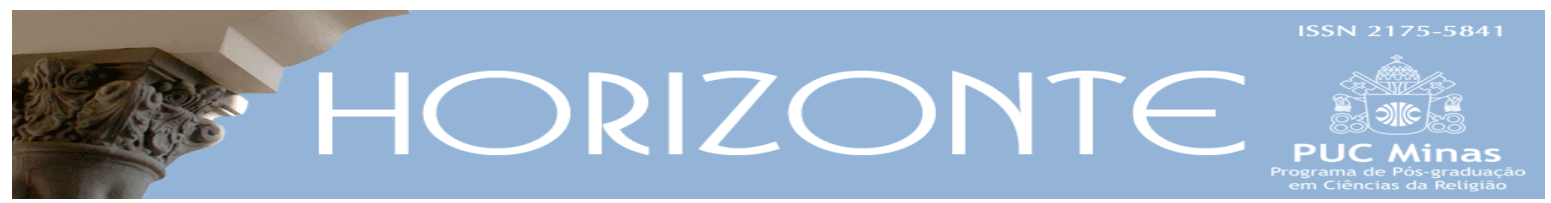

Dossiê: Fundamentalismos e Democracia - Temática Livre -Tradução (․) (-) DOI - 10.5752/P.2175-5841.2020v18n57p1334

\title{
Linguagem, epistemologia e mística
}

\author{
Language, epistemology, and mysticism
}

Steven T. Katz*

Tradução de Brasil Fernandes de Barros ${ }^{* *}$

Esse artigo foi originalmente publicado como capítulo do livro Mysticism and Philosophical Analysis, organizado por Steven T. Katz e publicado pela Oxford University Press em 1978. O texto trata de questões epistemológicas da mística e problematiza uma série de concepções dessa temática, tendo por principal objetivo marcar uma maneira de abordar os dados fornecidos pelos místicos, concentrandose especialmente na tentativa de defender a concepção de que assim como as ideias são mediadas por contextos culturais, sociais e religiosos, as experiências místicas são vivenciadas, ou como prefere dizer o autor, interpretadas, de formas diferenciadas de acordo com esses mesmos contextos.

As referências do original juntamente com a tradução do texto foram convertidas para normas da ABNT.

\section{PARTE I}

Gostaria de começar identificando vários elementos comuns na discussão da mística e de suas experiências, a fim de resolvê-los em primeira mão. Isso nos dará liberdade para que possamos nos concentrar em nossas principais preocupações

\footnotetext{
Texto submetido em 17 de janeiro de 2021 e aprovado em 29 de dezembro de 2020.

* Ph.D. from the University of Cambridge. Director of the Elie Wiesel Center for Judaic Studies at Boston University in Massachusetts, United States, where he holds the Alvin J. and Shirley Slater Chair in Jewish and Holocaust Studies.

** Doutorando em Ciências da Religião pelo PPGCR PUC Minas. Bolsista CAPES. País de origem: Brasil. E-mail: brasil@netinfor.com.br. ORCID: 0000-0002-5285-4871.
} 
epistemológicas. A primeira dessas características não é, na verdade, um problema, mas um conjunto de questões relacionadas entre si, que têm a ver com a natureza referente aos chamados estados místicos. A maneira mais fácil de introduzir essas preocupações é nos referindo aos termos “interpretação” e “verificação” e tudo o que essas noções sugerem ao leitor filosoficamente perspicaz. Vamos primeiramente lidar com a questão da verificação. Existem grandes, talvez insuperáveis, problemas envolvidos na questão da tentativa de verificar as alegações místicas, se por verificação nos referimos à forte tese de que os fundamentos independentes para o evento/experiência alegados podem ser demonstrados publicamente. Na verdade, parece-me, embora eu não tente justificar essa minha posição, de que não é possível fornecer esse tipo de “verificação". Como corolário dessa visão, também parece correto argumentar que nenhuma proposição verídica pode ser gerada com base na experiência mística. Como consequência, parece certo que a experiência mística não é, e logicamente não pode ser, a base para quaisquer afirmações finais sobre a natureza ou verdade de qualquer posição religiosa ou filosófica nem, mais particularmente, para qualquer crença dogmática ou teológica específica. Seja qual for a validade da experiência mística, ela não se traduz em "razões" que podem ser tomadas como evidências para uma dada proposição religiosa. Assim, em última análise, a experiência mística ou mais geralmente religiosa, é irrelevante para estabelecer a verdade ou falsidade de uma religião em geral ou de qualquer religião específica em particular $^{1}$.

Apesar da limitação estrita de valor a ser colocada nas justificativas da experiência mística, não está sendo argumentado aqui que essas experiências místicas não acontecem, ou que o que elas afirmam pode não ser verdade, apenas que não há bases para decidir sobre esta questão, isto é, de demonstrar que são de fato, verdadeiras. Além disso, mesmo que esta renúncia requeira uma declaração adicional de que, embora nenhum argumento filosófico seja capaz de provar a veracidade da experiência mística, seria dogmático e imprudente decidir a priori que as afirmações místicas são bobagens, especialmente dada a grande variedade

\footnotetext{
${ }^{1}$ Para uma defesa completa dessa posição, veja meu próximo artigo sobre "'Mystical Experience and Theological Truth". - N.T. - Em consulta feita diretamente junto ao autor, em 17 de fevereiro de 2021, fomos informados que este artigo nunca chegou a ser publicado.
} 
de tais reivindicações de homens de gênio e/ou intensa sensibilidade religiosa ao longo dos séculos, bem como em todas as faixas culturais. Nem parece razoável reduzir essas reivindicações múltiplas e variadas a meros "estados psicológicos" projetados que são apenas o produto de estados interiores de consciência.

O tópico relacionado à "interpretação" precisa também de uma breve menção, quer porque o sentido comum em que essa noção é tomada em relação ao nosso assunto não é nossa preocupação direta, quer porque o trabalho feito aqui me parece, apesar de algumas valiosas investigações iniciadas nesta área, serem ainda preliminares em termos de sua metodologia, bem como seus resultados. Quando falo de "interpretação" aqui, quero me referir aos relatos padrão do sujeito que tenta investigar o que o místico tinha a dizer sobre sua experiência. Esse empreendimento interpretativo é, obviamente, realizado em vários locais e de várias maneiras diferentes. Entre eles estão: (a) o relato em primeira pessoa do místico; (b) a "interpretação" do místico de sua própria experiência em algum estágio posterior, mais reflexivo e mediado; (c) a "interpretação" de terceiros dentro da mesma tradição (por ex. cristãos na mística cristã); (d) o processo de interpretação por terceiros em outras tradições (Budistas sobre o Cristianismo); e assim por diante. Além disso, todas essas formas de interpretação podem ser altamente ramificadas ou não, conforme o caso $^{2}$. Embora todos esses estágios na "interpretação" da experiência mística sejam importantes, à frente neste artigo, teremos oportunidade de retornar a certos aspectos que são, na sua maior parte, apenas tangenciais à nossa preocupação essencial e ainda mais básica, a "préinterpretativa”.

A questão da "interpretação", no entanto, levanta outra característica padrão da análise de estados místicos, que nos leva diretamente para onde queremos concentrar nossas atenções epistemológicas. Aqui, tenho em mente o esquema quase universalmente aceito da relação em que se afirma existir entre a experiência de um místico (e seu relato da experiência) e a experiência de outros místicos. Esse esquema assume três formas; uma menos sofisticada e outras duas, em graus diferentes, muitas vezes altamente sofisticadas. A menos sofisticada delas

\footnotetext{
${ }^{2}$ Veja a interpretação do ensaio de Ninian Smart e Mystical Experience em Religious Studies, vol. 1, número. 1 (1965).
} 
pode ser apresentada assim:

(I) Todas as experiências místicas são iguais; até mesmo suas descrições refletem uma semelhança subjacente que transcende a diversidade cultural ou religiosa.

A segunda forma, mais sofisticada, pode ser apresentada assim:

(II) Todas as experiências místicas são iguais, mas os relatos dos místicos sobre suas experiências são culturalmente limitados. Assim, eles usam os símbolos disponíveis de seu meio cultural-religioso para descrever sua experiência.

A terceira, e ainda mais sofisticada, pode ser apresentada da seguinte forma:

(III) Toda experiência mística pode ser dividida em uma pequena classe de "tipos" que ultrapassam as fronteiras culturais. Embora a linguagem usada pelos místicos para descrever sua experiência seja culturalmente limitada, a sua experiência não o é.

Uma palavra deve ser dita sobre cada uma delas. A Tese I é mais comumente encontrada na literatura inicial sobre o estudo da mística, e grande parte dela tendo sido gerada por atividades missionárias e relacionadas aos que procuravam encontrar algum denominador comum entre pessoas de origens religiosas amplamente diversas. Esse desejo ecumênico influenciou muitas das primeiras investigações sobre o assunto, além de ser responsável por torná-lo um objeto de estudo popular. Mais uma vez, uma segunda característica menos ecumênica, também pelo menos em parte, ligada ao empreendimento missionário inicial, que muitas vezes leva a esse tipo de argumento é a consideração dogmática, ou seja, que todas as religiões, mesmo que pareçam diferentes, realmente ensinam $x-\operatorname{com}$ a definição de $x$ sendo fornecida de forma variada com base nas crenças dogmáticas particulares que o intérprete mantém, por exemplo, o cristão descobre que $x$ é o Deus cristão3. Entre os resultados deste artigo, um deles será demonstrar que a Tese I está errada. Não há philosophia perennis, não obstante Huxley4 e muitos afirmarem isso.

A Tese II, embora mais sofisticada do que a de número I, também foi feita

\footnotetext{
${ }^{3}$ Ver, por exemplo, The Unknown Christ of Hinduism (Londres, 1964) de R. Panikkar e Kultmysterium in Hinduismus und Christentum (Munique, 1964).

${ }^{4}$ Ver Aldous Huxley, The Perennial Philosophy (Londres, 1946) e Fritjof Schuuon, The Transcendental Unity of Religions (Nova York, 1953).
} 
pelos mesmos motivos ecumênicos e dogmáticos que esta, visto que também apoia tais princípios. O ecumênico ou dogmático ainda é capaz de argumentar, com base na II, que alega ter por trás, ou acima, de todas as diferenças uma Verdade comum, e é isso que ele busca de qualquer maneira. $\mathrm{O}$ fato de que este tipo de reducionismo essencialista, ou seja, a redução de todos os relatos de x a uma alegada essência y, não ser geralmente passível de falsificação, nem de qualquer procedimento hermenêutico, metodológico ou metafísico claro é de pouca importância para os ecumênicos bem-intencionados ou para os dogmáticos convictos. Se alguém diverge do essencialista sobre o significado de um relato místico específico, ou de relatos místicos em geral, por exemplo, ao apontar as variações entre eles, é rejeitado como não os tendo compreendido, e todas as divergências são tomadas como resultado desse tal mal-entendido. Há, entretanto, algo mais a dizer sobre a Tese II, pois ela também ganhou destaque por pelo menos uma boa razão, isto é, o estudo mais desapaixonado, se ainda não completamente, dos dados místicos relevantes. Para estudantes acadêmicos sérios do assunto, que devem alguma fidelidade à academia, bem como a uma dada tradição, tornou-se inevitavelmente óbvio que nem todas as experiências místicas foram relatadas de maneira que facilmente sugiram ser todos relatos de uma mesma experiência. Apesar desta última virtude, a Tese II também deve ser rejeitada por ser inadequada para lidar com todas as evidências relevantes5.

A Tese III é ainda mais sofisticada, reconhecendo uma disparidade tanto de conteúdo quanto de forma nos relatos místicos. Os melhores estudos recentes sobre a mística pertencem a esta rubrica, como o trabalho de R. C. Zaehner6, W. T. Stace7, e N. Smart ${ }^{8}$. É mérito deles terem reconhecido os profundos problemas envolvidos em tentar classificar várias experiências místicas como iguais. No

\footnotetext{
${ }^{5}$ Ver, por exemplo, A. Leonard, 'Studies on the Phenomena of Mystical Experience' em Mystery and Mysticism (Londres, 1956); Mysticism East and West, de R. Otto (Nova York, 1957), e Mysticism Christian and Buddhist (Londres, 1957), de D. T. Suzuki. Veja também F. Heiler, Prayer (Londres, 1933); J. Marechal, Studies in the Psychology of the Mystics (Londres, 1927); William Johnston, The Still Point (Nova York, 1970); James Pratt, The Religious Consciousness (Nova York, 1930); E. Underhill, Mysticism (Londres, 1911).

${ }^{6}$ Os três principais estudos de mística de R. C. Zaehner são Hindu and Muslim Mysticism (Londres, 1960); Mysticism, Sacred and Profane (Londres, 1957; Nova York, 1961); e Concordant Discord (Londres, 1970). Veja também Our Savage God (Londres, 1974).

${ }^{7}$ As duas contribuições principais de W. T. Stace para o estudo da mística são The Teachings of the Mystics (Nova York, 1960); e Mysticism and Philosophy (Filadélfia, 1960; Londres, 1961).

${ }^{8}$ As principais contribuições de Ninian Smart para o estudo do misticismo são Reasons and Faiths (Londres, 1958); The Philosophy of Religion (Nova York, 1970); Interpretation and Mystical Experience em Religions Studies, vol. 1, $n^{\circ} .1$ (1965); 'Mystical Experience' em W. H. Capitan e D. Merrill (eds.) Art, Mind and Religion (Pittsburgh, 1967), p. 133-158; 'Mystical Experience' in Sophia, 1 (1962), p. 1925; 'History of Mysticism' em P. Edwards (ed.). Encyclopedia of Philosophy (Nova York), Vol. 5. Ver também o ensaio do Prof. Smart no presente volume.
} 
entanto, mesmo as posições de Zaehner ${ }^{9}$, Stace ${ }^{10}$, e Smart $^{11}$ são insatisfatórias porque tentam fornecer vários relatos fenomenológicos transculturais da experiência mística que são fenomenológica e filosoficamente suspeitos. A posição positiva que argumentaremos à frente neste artigo terá relação material com este tópico da categorização fenomenológica transcultural, pois tentará demonstrar que mesmo essas contas comparativamente sofisticadas permaneceram muito próximas da Tese II, o que demonstraremos ser inaceitável, mesmo que seja uma melhoria marcante em relação à Tese I. A título de antecipação e como conclusão provisória, será suficiente aqui sugerir que, por exemplo, as tipologias fenomenológicas de Stace e Zaehner são muito redutivas e inflexíveis, forçando formas multifárias e extremamente variadas da experiência mística em categorias interpretativas inadequadas que perdem vista às diferenças fundamentalmente importantes entre os dados estudados. Nesse sentido, poder-se-á mesmo dizer que todo este artigo é um “apelo ao reconhecimento dessas diferenças”.

\section{PARTE II}

O nosso interesse, não é, entretanto, o de adequar o enquadramento de uma tipologia para o estudo da experiência mística, apesar de que isso ocupe o palco central de quase todas as pesquisas importantes sobre a mística, que vai da clássica obra As Variedades das Experiências Religiosas, de William James, aos trabalhos de Underhill, Inge, Jones, Otto, Zaehner e Stace, essa é uma preocupação procedimental indutiva de segunda ordem. E dizemos que é de segunda ordem porque se trata de uma investigação mais básica já que as várias experiências

\footnotetext{
${ }^{9}$ Para críticas a Zaehner, consulte as páginas 11 a 14 a seguir.

${ }^{10}$ Para a crítica de Stace, veja as páginas 8-10 a seguir. Também é importante reconhecer o viés fundamental de Stace em favor de uma descrição monística da mística que vê o monista como uma forma mais autêntica de mística. Este preconceito corrompe muito de seu manuseio de evidências e a natureza de seus argumentos e julgamentos. Ver também W. J. Wainwright, "Stace and Mysticism", em Journal of Religion, 50 (1970), p. 139-154.

${ }^{11}$ Os estudos de Smart são problemáticos neste ponto crucial e, às vezes, ele até mesmo se entrega ao que chamamos de Tese II. Assim, por exemplo, ao resumir os resultados de sua crítica a Zaehner em seu artigo sobre "Interpretation and Mystical Experience" em Religious Studies, vol. 1, № 1 (1965), ele escreve: "Para colocar a possibilidade de que eu esteja fazendo uma investigação de forma simplória, ela pode ser reduzida às seguintes teses:

1. Fenomenologicamente, a mística é a mesmo em todos os lugares.

2. Diferentes sabores, no entanto, surgem nas experiências dos místicos por causa de seus diferentes modos de vida e modos de autointerpretação.

3. A verdade da interpretação depende em grande medida de fatores extrínsecos à própria experiência mística."
} 
místicas são o que são ${ }^{12}$.

Para que possamos chegar a uma concepção mais clara do que pretende este artigo quando se fala da questão de "Por que as experiências místicas são as experiências que são?”, meu posicionamento a esse respeito é que a única suposição epistemológica que me faz empreender a presente investigação é a seguinte: NÃO existem experiências puras (ou seja, não mediadas). Nem a experiência mística nem as formas mais comuns de experiência dão qualquer indicação, ou qualquer base, para acreditar-se que não são mediadas. Isso significa dizer que toda experiência é processada, organizada e colocada à nossa disposição de maneiras epistemológicas extremamente complexas. A noção de experiência não mediada parece, se não contraditória, na melhor das hipóteses, vazia. Esse fato epistemológico me parece verdadeiro, por causa dos tipos de seres que somos, mesmo no que diga respeito às experiências daqueles objetos últimos de preocupação com os quais os místicos têm relações, por ex. Deus, Ser, nirvānaa, etc. Este aspecto "mediado" de toda a nossa experiência parece uma característica inevitável de qualquer investigação epistemológica, incluindo a investigação da mística, que deve ser devidamente reconhecida se nossa investigação da experiência, incluindo a experiência mística, for muito além. No entanto, entre todos os trabalhos dos grandes investigadores da experiência mística a que tive acesso, esta característica da experiência foi de alguma forma negligenciada13. Uma avaliação adequada desse fato leva ao reconhecimento de que, para compreender a mística, não basta apenas o estudo dos relatos do místico após o evento experiencial, mas o reconhecimento de que a experiência em si, bem como a forma em que é relatada, são moldadas por conceitos que o místico traz e que moldam sua experiência. Para tornar isso algo mais concreto, o que argumentamos é que, por exemplo, o místico hindu não tem uma experiência x que ele então descreve para si mesmo em uma linguagem familiar com os símbolos do Hinduísmo, ao invés disso, ele tem uma experiência hindu, isto é, sua experiência não é uma experiência não

\footnotetext{
${ }^{12}$ Vamos tratar de forma crítica essas tipologias fenomenológicas, mais tarde neste artigo, no entanto, à luz de nossa tese mais geral sobre a natureza da experiência mística.

${ }^{13}$ Li todos os grandes estudos sobre este assunto que me foram apresentados e na minha análise os únicos dois estudiosos do tema que parecem reconhecer o pleno significado e as implicações deste assunto de forma sistemática para o estudo da mística são R. C. Zaehner e Ninian Smart. No entanto, mesmo eles fazem muito pouco. O ponto também é reconhecido num contexto restrito por $\mathrm{H}$. P. Owen em seu artigo sobre "Christian Mysticism" em Religious Studies 7 (1971), p. 31-42.
} 
mediada de x, mas é ela própria, pelo menos parcialmente, a experiência hindu, antecipada e pré-formada de Brahman. Novamente, o místico cristão não experimenta alguma realidade não identificada, que ele então rotula convenientemente de Deus, mas, ao invés disso, tem as experiências cristãs de Deus, ou de Jesus, ou semelhantes, e pelo menos parcialmente prefiguradas. Além disso, como alguém poderia ter antecipado, é minha opinião baseada nas evidências que existem que a experiência hindu de Brahman e a experiência cristã de Deus não são as mesmas. Devemos, pois, apoiar a afirmação a seguir. O significado dessas considerações é que as formas de consciência que o místico traz para a experiência estabelecem parâmetros estruturados e limitantes sobre o que será a experiência, ou seja, sobre o que será experimentado, e que descartam antecipadamente o que é "não-vivenciado", de forma particular e concreta naquele contexto. Assim, por exemplo, a natureza da consciência pré-mística do místico cristão informa a consciência mística de tal forma que ele experimenta a realidade mística em termos de Jesus, da Trindade ou de um Deus pessoal, etc., ao invés de, em termos da doutrina budista, do não pessoal, de não tudo do nirvāṇa ${ }^{14}$. Deve-se tomar cuidado ao observar que mesmo a pluralidade das experiências encontradas nas tradições místicas hindus, cristãs, muçulmanas, judaicas, budistas etc., deve ser dividida em unidades menores. Assim, encontramos, por exemplo, no Hinduísmo 15 tendências monísticas, panteístas e teístas, enquanto o Cristianismo conhece formas absortivas e não absortivas de mística. E, novamente, muita atenção deve ser dada às mudanças orgânicas na ideologia e no desenvolvimento histórico pelas quais tradições específicas sofrem internamente, e como essas mudanças afetam as experiências místicas dos místicos, respectivamente, em cada tradição. Por exemplo, a mística absortiva não é encontrada nos primeiros estratos da mística cristã, enquanto novamente a experiência mística judaica dos tempos talmúdicos, conhecida como mística merkabah, com base na visão da carruagem de Ezequiel, é diferente da mística do final da Idade Média, Zoharica (final do século XIII) e

\footnotetext{
${ }^{14}$ Para uma discussão técnica da doutrina budista do nirvāna, ver D. Kalupahana, Buddhist Philosophy (Hawai, 1976), p. 69-90; C. Prebish (ed.), Buddhism: A Modern Perspective (Pensilvania, 1975); L. de la Vallee Poussin, Nirvana (Paris, 1923); I. B. Horner, The Early Buddhist Theory of Man Perfected (Londres, 1936); R. Johansson, The Psychology of Nirvana (Nova York, 1970); T. Stcherbatsky, The Buddhist Conception of Nirvana (Leningrado, 1927); G. R. Welbon, The Buddhist Nirvana and Its Western Interpreters (Chicago, 1968).

${ }^{15}$ R. C. Zaehner, por exemplo, afirma identificar quatro tipos distintos de mística no Hinduísmo. Ver sua obra Concordant Discord (Londres, 1970), p. 204 e seguintes.
} 
Luriânica (século XVI e em diante), mais minuciosamente permeada por elementos gnósticos. E, repito, o restante deste artigo tentará fornecer toda a evidência para o apoio e a argumentação de que este processo de diferenciação da experiência mística nos padrões e símbolos de comunidades religiosas estabelecidas é experiencial e não ocorre apenas no período pós-experiencial do processo de relatar e interpretar a própria experiência: isso acontece antes, durante e depois da experiência.

Poderemos perceber a importância da questão que está sendo levantada, bem como a falha em reconhecê-la, se olharmos para a discussão extremamente influente de mística e filosofia feita por W. T. Stace (1961, p 31-38). No capítulo de abertura da obra de Stace intitulado Presuppositions of the Inquiry, o autor assume a distinção familiar entre experiência e interpretação e argumenta que esta é uma distinção que deve ser respeitada, embora ele sustente que geralmente mesmo os melhores investigadores do assunto não a respeitam. No decorrer desta discussão, ele dá o seguinte exemplo de abertura que parece bem promissor.

É praticamente impossível ... isolar a experiência "pura". No entanto, embora possamos nunca sermos capazes de encontrar a experiência sensorial completamente livre de qualquer interpretação, dificilmente poderemos duvidar de que uma sensação é uma coisa e sua interpretação conceitual seja outra. Isto é, elas são distinguíveis, embora não completamente separáveis. Há uma anedota apócrifa, sem dúvida bem conhecida, sobre um visitante americano em Londres que tentou apertar a mão de um policial de cera na entrada do Madame Tussaud's. Se tal incidente de fato já aconteceu, deve ter sido porque o visitante teve uma experiência sensorial que ele interpretou erroneamente como sendo de um policial vivo e logo em seguida o interpretou corretamente como uma figura de cera. Se a frase que acabo de escrever é inteligível, isso prova que uma interpretação pode ser distinta de uma experiência; pois de outra forma não poderia haver duas interpretações de uma mesma experiência. (STACE, 1961, p. 31).

Stace faz ainda acréscimos à observação correta sobre o evento no Madame Tussaud's.

Houve nesse caso duas interpretações sucessivas, embora possa ser verdade que, em nenhum momento, a experiência tenha sido isenta de interpretação, mesmo que tal experiência pura seja psicologicamente impossível. Sem dúvida, o algo original visto na entrada foi imediatamente reconhecido como algo material, que tinha cor e forma geral de um ser humano. E como se tratava da aplicação de conceitos classificatórios às 
sensações, houve desde o início algum grau de interpretação. Entendo que seria seguro dizer que há uma distinção inteligível entre experiência e interpretação, mesmo que seja verdade que nunca possamos chegar a uma experiência totalmente não interpretada. (STACE, 1961, p. 31).

No entanto, depois deste início auspicioso de sua investigação, na verdade no próprio argumento que Stace gera a partir daí, fica evidente que ele não compreendeu de forma clara a força da preocupação a respeito da impossibilidade de uma experiência "pura" e no que isso implica. Ele, pois, transforma essa discussão em uma discussão de interpretação da pós-experiência colocada na experiência, ao invés de buscar em todos os sentidos o que o reconhecimento das questões epistemológicas primárias originais exige. Logo em seguida, ele se volta para "a dificuldade de decidir que parte do relato descritivo de uma experiência mística deve ser considerada como realmente experimentada e que parte deve ser tomada como sua interpretação". Para depois, novamente de forma ingênua, voltar-se para a questão se todas as experiências místicas são iguais ou não, com base na discussão de seus relatos pós-experienciais.

Agora a primeira questão, que é uma pergunta extremamente difícil de ser respondida, é: Até que ponto as experiências místicas relatadas por cristãos, muçulmanos, judeus, hindus e budistas, e por místicos que não foram adeptos de nenhum credo religioso específico, são semelhantes ou diferentes? Teremos que lidar com isso, mas não podemos esperar que consigamos chegar perto de uma resposta verdadeira, a menos que façamos a distinção entre experiência e interpretação e nos esforcemos para aplicá-la ao nosso conteúdo. A razão disso pode ser explicada pelo exemplo a seguir:

O místico cristão geralmente diz que o que ele experimenta é a "união com Deus". O místico hindu diz que sua experiência é aquela em que seu eu individual é idêntico a Brahman ou ao Eu Universal. O cristão diz que sua experiência apoia o teísmo e não é uma experiência de identidade real com Deus, e ele entende a "união" como não envolvendo identidade, mas alguma outra relação, como "semelhança". O hindu insiste na identidade e diz que sua experiência estabelece o que os escritores sobre mística costumam chamar de "panteísmo" - embora os hindus geralmente não usem essa palavra ocidental. O místico budista - pelo menos de acordo com algumas versões do budismo - não fala de Deus ou Brahman ou um Eu Universal, mas interpreta sua experiência em termos que não incluem o conceito de um Ser Supremo.

Existem, portanto, grandes diferenças de crença aqui, embora todas as crenças sejam igualmente consideradas como fundadas em experiências místicas. (STACE, 1961, p. 34). 
O fracasso de Stace em apreciar a complexidade da natureza da "experiência" com seu contexto linguístico, social, histórico e conceitual, e as severas limitações de sua ênfase em uma distinção concebida ingenuamente, entre experiência e interpretação, tornam-se claras quando ele assume o que ele considera ser a posição argumentada por Zaehner, em Mysticism Sacred and Profane. Nessa obra Zaehner argumenta que os relatos místicos originais revelam experiências diferentes, não somente relatos diferentes da mesma experiência; ou seja, não se trata apenas de reconhecer a distinção entre experiência e interpretação e, em seguida, simplesmente confrontar interpretações alternativas do mesmo dado. Stace tenta responder à tese de Zaehner sugerindo isso:

O professor Zaehner, que é católico romano, reitera que essas experiências [dos místicos cristãos e hindus] devem ter sido diferentes. Porque Eckhart e Ruysbroeck construíram seus relatos da experiência a partir da teologia trinitária ortodoxa que aceitaram da Igreja, enquanto os hindus a entenderam panteisticamente - entendendo que o panteísmo, segundo os teólogos católicos, é uma séria "heresia". ... a questão é de que a conclusão do professor Zaehner não decorre simplesmente do fato de que cristãos e indianos fundamentam suas crenças de forma diferenciadas. E que a diferença de crenças é realmente a única evidência que ele oferece para seu ponto de vista. Uma compreensão genuína da distinção entre experiência e interpretação, e especialmente das dificuldades envolvidas na sua aplicação, poderia ter resultado em um exame e tratamento mais completo, justo e imparcial das duas hipóteses possíveis. (STACE, 1961, p. 36).

É altamente instrutivo notar que Stace tenta rejeitar a acusação de Zaehner com base na distinção entre experiência e interpretação, sem reconhecer a necessidade de fazer a pergunta fundamental: o que o cristão traz para sua experiência e como isso afeta essa experiência, e o que o hindu traz para sua experiência e como isso afeta essa experiência? O foco das observações de Stace está na relação entre a experiência dos místicos e "as crenças em que os místicos se basearam em suas experiências”. Aqui, a simetria é sempre unidirecional: da "experiência” às "crenças". Não há reconhecimento de que essa relação contém uma simetria bidirecional: as crenças moldam a experiência, assim como a experiência molda a crença. Para tomar, por enquanto, um exemplo não controverso disso, considere as pinturas de Notre Dame de Manet. Manet "sabia" que Notre Dame era uma catedral gótica e, portanto, "a via” como uma catedral 
gótica, conforme atestam suas pinturas que a apresentam com arcos góticos. No entanto, um exame mais atento revelará que algumas das arcadas de Notre Dame que Manet pintou como góticas são na verdade românicas ${ }^{16}$. Como Coleridge nos lembrou: "a mente vê em parte e cria em parte". A reflexão agora também nos lembra que Stace não conseguiu de forma semelhante avaliar a necessidade de investigar as questões profundas envolvidas no que o visitante americano do Madame Tussaud trouxe para sua experiência. Para que possamos tratar de forma adequada as ricas evidências apresentadas pelos místicos, não será suficiente a ênfase dada apenas aos relatos pós-experienciais e o uso de uma diferenciação simplista - como é quase universalmente aceita pelos pesquisadores - entre a alegada "experiência bruta" e a interpretação.

Como Stace mencionou Zaehner, um outro importante pesquisador moderno do assunto, vamos avaliar brevemente o seu relato. Zaehner, um orientalista muito eminente e detentor da Cátedra Spalding em Religiões Orientais na Universidade de Oxford de 1953 a 1967, em contraste com Stace, está ciente que tanto em virtude de sua formação, quanto em relação à experiência pessoal ${ }^{17}$, que não é tão fácil reunir todas as experiências místicas em uma categoria basicamente indiferenciada ${ }^{18}$. De fato, em suas palestras em Gifford, ele escreve com respeito especial ao Hinduísmo, mas para fazer um ponto mais geral, que o Hinduísmo "desmente ... a presunção fácil de que 'a mística é essencialmente uma e a mesma, qualquer que seja a religião professada pelo místico individual"' (ZAEHNER, 1970, p. 194). Zaehner, além disso, observa corretamente que a visão de que a mística é "um fenômeno constante e inabalável do anseio universal do espírito humano por uma comunhão pessoal com Deus" (ZAEHNER, 1970, p. 194), embora verdadeiro para a mística ocidental e, portanto, perdoável como uma descrição desta, é inadequado, ou até mesmo impreciso quando aplicado ao "tipo de mística com o qual nos familiarizamos nos Upanishads, quanto mais com a experiência do nirvana conforme descrito nos primeiros textos budistas" (ZAEHNER, 1970, p.

\footnotetext{
${ }^{16}$ Para mais detalhes deste tipo de fenômeno na percepção artística, veja E. H. Gombrich, Art and Illusion (Londres, 1960). Ver também o ensaio de Gombrich “The Evidence of Images" em C. S. Singleton (ed.), Interpretation (Baltimore, 1969), p. 35-104.

${ }^{17}$ Veja a "Introdução à Mística" de Zaehner, em Mysticism, Sacred and Profane onde ele se refere à sua própria experiência mística, natural e juvenil aos 20 anos de idade (p. xii e seguintes). Ver também Our Savage God (Londres, 1974), p. 209-210.

${ }^{18}$ Embora Stace divida a experiência mística em dois tipos, "introvertida" e "extrovertida", ele sustenta que ambas são realmente formas de um padrão de absorção mais definitivo de um tipo monístico. Portanto, esta divisão é realmente apenas heurística e preliminar.
} 
194). No entanto, apesar do insight de Zaehner sobre a necessidade de reconhecer a diversidade das evidências místicas, existem graves deficiências em sua posição que o impedem de dar a contribuição que pretendia para o assunto. As deficiências de sua abordagem são de três tipos: primeiro, há a objeção correta de que a evidência de Zaehner é composta exclusivamente de testemunhos pósexperienciais e que, por um lado, não respeita a distinção experiência-interpretação de uma forma que seja eficientemente rigorosa para satisfazer Stace, nem por outro lado - e este é o ponto crucial para nossa preocupação, ao qual Stace está não está atento - faz a investigação necessária sobre as condições lógicas e sociocontextuais da experiência mística que justificariam rejeitar a sua distinção simplista. Em segundo lugar, os fortes preconceitos católicos de Zaehner colorem toda a sua investigação e fazem muito de seu trabalho parecer um apelo especial pelo Cristianismo católico, ou pelo menos pelo monoteísmo ocidental em oposição ao monismo oriental. Por exemplo, em sua obra Hindu and Muslim Mysticism, Zaehner imprudentemente, para não dizer dogmaticamente, escreve: “Tanto Najm al-Dīn Rāzì, defendendo a ortodoxia islâmica, quanto Ibn Tufayl, defendendo a sanidade, expõem a pretensão monista de ser Deus como o 'conceito equivocado' que esta pretensão tanto manifesta"19; enquanto, novamente, em sua obra Mysticism Sacred and Profane, ele tenta relacionar os diferentes tipos de mística, especialmente aquele entre o que ele chama de mística monística e teísta, com sua própria compreensão cronológica da queda de Adão ${ }^{20}$.

Por fim, a fenomenologia de Zaehner não é satisfatória. É sim, mais sofisticada do que a de Stace e de quase todos os pesquisadores anteriores, e suas verdadeiras realizações devem ser reconhecidas. No entanto, os pontos de vista de Zaehner não servirão como uma declaração final do problema, ou até mesmo como uma declaração provisória, porque ela é interrompida prematuramente em sua busca pelo(s) significado(s) completo(s), o que leva a um reconhecimento da diversidade relevante da natureza e da experiência mística, especialmente em termos de seus contextos, de suas condições em relação a linguagem, crenças e

\footnotetext{
${ }^{19}$ Ver R. C. Zaehner, Hindu and Muslim Mysticism (Londres, 1960), p. 188.

${ }^{20}$ Sobre isso, consulte a bizarra discussão em R. C. Zaehner, Mysticism, Sacred and Profane (Londres, 1957; Nova York, 1961), p. 191192. Para uma discussão crítica da posição de Zaehner, veja N. Smart, "Interpretation and Mystical Experience", Religious Studies, vol. 1, n. 1 (1965); F. Staal, Exploring Mysticism (Londres, 1975). Ver também as críticas de N. Pike a Smart, "Comments", em W. H. Capitan e D. D. Merrill (eds.), Art, Mind and Religion (Pittsburgh, 1967), p. 144-150.
} 
configurações culturais. Como consequência, sua tripla distinção tipológica para lidar com experiências místicas transculturais - o teísta, o monista e o naturalista ("panenhénico" no vocabulário de Zaehner) - acaba por ser um avanço sobre a maioria dos relatos alternativos, como já dissemos, embora excessivamente simplista e reducionista. Por exemplo, tanto os místicos judeus quanto os cristãos são, em sua maioria, teístas no sentido amplo, mas a experiência dos místicos judeus é radicalmente diferente daquela encontrada nos círculos cristãos. E novamente o "teísmo" da Bhagavad Gita ou de Ramanuja é marcadamente diferente do teísmo de Teresa de Ávila, Isaac Luria, ou Al Hallaj. Alternativamente, o monismo de Shankara não é o monismo de Spinoza ou Eckhart. E mais uma vez o Budismo, por exemplo, apesar de classificado de acordo com a fenomenologia de Zaehner como monista, não deve realmente ser tão compartimentado ${ }^{21}$. Zaehner apresenta esta identificação "monística" do Budismo somente através do uso indevido dos textos, atribuindo às doutrinas budistas pontos que elas não possuem, sendo especialmente surpreendente a este respeito sua atribuição da doutrina de ātman, a doutrina de um “eu” substancial, à Buda. Não obstante este fato, Zaehner parece ter feito da negação da doutrina de âtman, que era fundamental para o Hinduísmo, o ponto central, senão mesmo a base, de sua própria posição revolucionária. Assim, o suposto "monismo" dos budistas que negam a existência de um eu ou alma substancial dificilmente poderia ser equiparado, exceto pela manipulação de evidências e ignorância dos fatos, como, digamos, a experiência monística Advaita em que afirma existir um Eu universal, Brahman, que é a base de todo ser e no qual cada indivíduo em particular participa e encontra sua salvação final. As bem conhecidas investigações de Zaehner são frágeis porque seus recursos metodológicos, hermenêuticos, e especialmente epistemológicos, são fracos. De fato, suas pesquisas reforçam a necessidade sentida de buscar tais investigações em termos conceituais mais sofisticados.

Esta deficiência de investigar ou de considerar na investigação da experiência mística as condições da experiência em geral e as condições específicas da experiência religiosa/mística em particular é uma deficiência que distorce toda

\footnotetext{
${ }^{21}$ Para uma discussão aprofundada deste ponto ao qual sou grato, N. Smart, "Interpretation and Mystical Experience" em Religious Studies, v. 1, n. 1 (1965), p. 81-84.
} 
essa discussão, de forma que passa a desvirtuar toda e qualquer conclusão ou sugestão que possam ser feitas a esse respeito. Voltemos, portanto, a este tema. Recordemos, inicialmente, a sabedoria da observação: "a criança é pai para o homem". Isto vale também para a investigação epistêmica, tanto no que diz respeito ao aspecto lógico-conceitual da investigação quanto ao aspecto culturalsocial, embora, é claro, o aspecto lógico-conceitual envolve ideias e condições que, em outro nível, devem ser estritamente divorciadas desse tipo de abordagem, como veremos. Vamos investigar o significado metodológico dessa frase, tomando, a princípio, como ela se aplica no caso de um místico judeu.

$\mathrm{Na}$ esfera sociocultural, o místico judeu terá sido, desde sua infância, ensinado e condicionado de todas as maneiras: (1) que há mais na realidade do que este mundo físico; (2) que este "mais" do que a realidade física é uma Realidade última que é um Deus pessoal; (3) que este Deus criou o mundo e os homens; (4) que os homens têm almas espirituais que comungam com Deus; (5) que Deus estabelece alianças com os homens; (6) que mesmo em suas alianças Ele permanece distinto; (7) que o Ser de Deus e o ser do homem são ontologicamente distintos; (8) que Deus celebrou alianças especiais com Abraão e com os herdeiros de Israel; (9) que essas alianças se expressam nos atos de circuncisão e de doação da Torá; (10) que a Torá e seus mandamentos (mitzvot) são a mais perfeita expressão da vontade de Deus, bem como o meio mais perfeito de relação entre o homem e Deus, e assim por diante. Além disso, o místico judeu terá aprendido a adequar todos esses itens em uma "teologia mística" especial conhecida pelo termo amplo de Cabala, na qual o visível e perceptível é o irreal e o não perceptível e não sensual é o real. Pode-se ampliar esta lista comparativamente pequena em grande extensão. Todas estas crenças socioculturais e suas práticas correspondentes, especialmente na miríade de práticas do mitzvot, afetam claramente a maneira como o místico judeu vê o mundo, o Deus que o criou, a maneira de se aproximar deste Deus, e o que esperar quando finalmente se aproxima deste Deus. Ou seja, toda a vida do místico judeu é permeada desde a infância por imagens, conceitos, símbolos, valores ideológicos e comportamentos rituais os quais não há razão para acreditar que ele as deixará para trás em sua experiência. Ao contrário, estas imagens, crenças, símbolos e rituais definem, antecipadamente, como será a 
experiência que ele quer ter, e que ele então terá. Sem tornar a discussão muito complexa em seus detalhes da teoria e prática mística judaica (tradicionalmente chamada de Cabala teórica e Cabala prática, embora haja muita sobreposição e a última se baseie na teologia da primeira), consideremos a característica mais essencial do pensamento místico judeu e seu comportamento relacionado, exclusivo dos místicos judeus, a saber, a centralidade da atuação do mitzvot (mandamentos) para alcançar o objetivo místico e como esta interpenetração de ações rituais e éticas (mitzvot) com o objetivo de relação com Deus afeta o tipo de experiência que se antecipa ter e que, de fato, acontece ${ }^{22}$.

O místico judeu realiza o mitzvot como uma necessidade no caminho do místico porque ele concebe a si mesmo, ao mundo (ou cosmos), e a Deus de uma forma muito especial. O mais importante, talvez, entre os elementos de sua autoconsciência está sua concepção de Deus como o tipo de Ser que é de alguma forma pessoal e, mais ainda, que é ética e avaliativamente pessoal, ou seja, um Deus que é afetado por boas ações e atos de obediência, e a relação com Quem é afetado pelo desempenho adequado das ações prescritas. Assim, a experiência do místico judeu é uma experiência pré-condicionada de um Deus (moral-pessoal). Vemos este elemento configurativo pré-experiencial, por exemplo, nos detalhes da doutrina cabalística central na relação da ação humana e dos Sefirot (Emanações Divinas que compreendem os níveis mais altos dos mundos superiores), na qual cada Sefirá está relacionada a uma contraparte ética humana, de modo que o perfeito desempenho do comportamento ético se torna, acima de tudo, o caminho para a relação com estas Emanações Divinas. Entretanto, geralmente o nível de experiência com os diferentes degraus dos Sefirot (dos quais são dez) depende do comportamento ético e ritual (mitzvot), e especialmente da oração feita com o compromisso e a concentração corretos (conhecidos como kavaná). Os místicos judeus acreditam que tal oração mística conduz a alma em sua ascensão porque a oração mística leva a um reconhecimento e a um contato com o verdadeiro significado dos "Nomes" de Deus, que são a verdadeira estrutura ontológica dos

\footnotetext{
${ }^{22}$ Para mais materiais sobre a tradição judaica ver S. Katz, Jewish Concepts (Nova York, 1977); E. Urbach, The Sages (Jerusalém, 1975); S. Schecter, Some Aspects of Rabbinic Theology (Nova York, 1961); H. Donin, To Be a Jew. (Nova York, 1972); G. F. Moore, Judaism (Nova York, 1972); G. F. Moore, Judaism (Nova York, 1973); M. Steinberg, Basic Judaism (Nova York, 1947).
} 
mundos superiores ${ }^{23}$.

Esse complexo padrão pré-experiencial afeta a experiência real do místico judeu, de forma a nos levar a uma conclusão incontestável, que pode ser verificada de forma clara na experiência do místico judeu, ou melhor dizendo, em referência à sua “não experiência”. Isso significa dizer que o condicionamento judeu, tanto para os místicos da tradição como todos os outros judeus, é fortemente impactado com o fato de não se ter a rara experiência mística de unidade com Deus, na qual se perde a identidade em momentos extáticos, se é que alguma vez a vivenciará. O que o místico judeu experimenta é, talvez, o Trono Divino, ou o anjo Metatron, ou aspectos dos Sefirot, ou a corte celestial e palácios, ou a Torá Escondida, ou os Nomes Secretos de Deus, mas não a perda de si mesmo em unidade com Deus. A ausência dos tipos de experiência de unidade que muitas vezes, mas equivocadamente, associa-se à mística, "mesmo como sua a essência", neste contexto místico judeu, é uma evidência muito forte de que o condicionamento pré-experiencial afeta a natureza da vivência que realmente se tem. Como o judeu é ensinado que tais experiências de unidade não acontecem por razões que fluem da tradição teológica judaica, ele não tem, de fato, tais experiências ${ }^{24}$. Este é um elemento formativo pré-experiencial e não apenas um fato pós-experiencial imposto pelas exigências ortodoxas judaicas, como Stace poderia sugerir, sendo esse o caráter essencial da própria experiência. A lógica da experiência exige a adoção deste relato e as evidências o apoiam. ${ }^{25}$

Não há evidência, senão a priori teorizada, diante da comprovação real do contrário, que essa caracterização não unitiva da experiência do místico judeu é meramente o produto do relatório pós-experiencial, cuja forma é necessária pelas ortodoxias sociais ou religiosas e imposta ao que, de fato, foi basicamente uma experiência de um tipo totalmente diferente (unitiva). Ao contrário, essas

\footnotetext{
${ }^{23}$ Ver G. Scholem's Kabbalah (Nova York, 1974) e On the Kabbalah and its Symbolism (Nova York, 1965).

${ }^{24}$ Para mais informações sobre "Devekuth” veja G. Scholem's Kabbalah (Nova York, 1974); Major Trends in Jewish Mysticism (Nova York, 1954); e seu ensaio "Devekuth" em sua obra The Messianic Idea in Judaism (Nova York. 1972), p. 203-226. Para material adicional de importância, e um desacordo com a visão de Scholem, ver I. Tishby's Mishnat Ha-Zohar [em hebraico] (Jerusalém, 1961), Vol. 2, p. 287 e seguintes. A posição de Scholem, entretanto, parece-me ser a substancialmente correta.

${ }^{25} \mathrm{O}$ ponto de vista de Ninian Smart, conforme declarado em seu artigo "Interpretation and Mystical Experience", in Religious Studies, vol. 1, n. 1 (1965), parece-me também estar equivocado sobre este assunto. Sua posição é muito próxima da de Stace ao enfatizar a distinção entre "experiência" e sua "interpretação" e falha, creio eu, em ver a importância essencial do pré-condicionamento da experiência do místico. Ela escreve: "Isto me parece uma clara indicação de que as experiências monísticas e teístas são essencialmente semelhantes; e que é a interpretação correta delas que está em questão" (p. 85).
} 
preocupações ortodoxas, que são de fato muito reais, e são muito mais profundamente enraizadas e poderosas, moldam as capacidades imaginativas e experienciais do místico judeu desde a infância e pré-formam seu esquema perceptivo de organização. No entanto, Stace, por exemplo, só vê este aspecto construtivo dos fatores externos à medida que eles trabalham na consciência interna em termos do relatório pós-experiencial, e não em termos de seu caráter antes e depois - uma curiosa cegueira em apoio a uma teoria apaixonadamente sustentada.

Continuemos um pouco mais com esse exemplo para que possamos desenvolver implicações mais profundas. Na tradição mística judaica, o estado final da experiência mística é chamado de devekut, o que literalmente significa "uma adesão" ou "um apego" a Deus. Ou seja, na tradição judaica, a forte ênfase monoteísta na singularidade de Deus é entendida não só como a compreensão de sua unidade numérica e de perfeição, mas também como sua distinção qualitativa, ontológica, de suas criações. E mesmo que esta distinção seja um pouco difusa na Cabala Zohárica e depois na Cabala Luriânica, com suas teorias de emanação e não de criação, mesmo ali a majestade transcendental e distintiva de Deus é essencial e é retida pela referência a Deus em si como Ein Sof, literalmente "sem fim”, mas usada de forma mais ampla para se referir à Alteridade última e radical de Deus e à incompreensibilidade, tanto epistemologicamente como ontologicamente. Como consequência, os místicos judeus vislumbraram o objetivo final da relação mística, devekut, não como absorção em Deus, ou como unidade com o divino, mas como uma intimidade amorosa, um “apego a” Deus, uma relação em que o tempo todo se está consciente da dualidade de Deus e do místico, ou seja, que experimenta Deus como Outro e não como Self. Toda a literatura mística judaica reflete este ensino do devekut como o objetivo a ser buscado e, ainda mais importante, todos os testemunhos místicos judaicos estão de acordo com este padrão. Agora se poderia dizer: "mas isto é por causa da pressão social” - mas qual evidência há para se dizer isto? Além disso, não é mais razoável relacionar o meio formador com a própria experiência e depois ler as evidências disponíveis como confirmação do caráter do meio que afeta a totalidade da experiência, em vez de contabilizar o material de maneiras mais artificiais? 
Para tornar nosso ponto de vista ainda mais claro, vamos mudar nosso foco e comparar a experiência judaica do devekut com uma experiência mística radicalmente diferente encontrada em uma tradição mística próxima à outra ponta do espectro místico, a do budista. O pré-condicionamento da consciência budista é muito diverso da consciência judaica e esta diferença gera uma experiência mística radicalmente diferente que o budista almeja e alcança. Considere, por exemplo, os seguintes elementos concretos que o budista apreende de sua tradição a partir das "quatro nobres verdades" que são o fundamento de sua tradição. Estas verdades são:

(a) "Nascer é sofrimento, envelhecer é sofrimento, doença é sofrimento, morte é sofrimento, associação é sofrimento, separação do que é agradável é sofrimento, não obter o que se deseja é sofrimento ...”;

(b) A causa do sofrimento é "ânsia" ou "desejo", "ânsia por desejos sensuais e ânsia por vir a ser e ânsia por não existir";

(c) O sofrimento pode ser superado pela disciplina e compreensão adequadas;

(d) Existe um caminho óctuplo que leva à cessação do sofrimento (ou seja, nirvāna).

Este caminho óctuplo se constitui pela(o): (1) Compreensão correta, ou seja, compreensão das quatro verdades nobres; (2) Pensamento correto, ou seja, pensamento livre de desejo e de crueldade. Isto é chamado de Samkalpa, a "formação conjunta" adequada da consciência; (3) Discurso correto, ou seja, evitar mentiras, calúnias, fofocas maliciosas, discurso frívolo; (4) Ação correta, ou seja, evitar especialmente matar, roubar e má conduta em geral; (5) Meios de subsistência corretos, ou seja, não ganhar a vida por meios inadequados, por exemplo, como astrólogo; (6) Esforço correto, ou seja, esforçar-se para purificar-se de pensamentos malignos; (7) Consciência correta, ou seja, estar devidamente atento à natureza do próprio corpo e mente; (8) Concentração correta, ou seja, praticar os padrões adequados de meditação, especialmente os quatro estados de dhyānas ou transe. Assim, vemos que o budista está condicionado a alcançar o nirvāṇa pela śìla ou seu comportamento moral, samādhi ou concentração e prajña 
ou sabedoria. ${ }^{26}$

Os elementos das quatro nobres verdades foram então aprofundados no segundo grande sermão de Buda, o "Discurso sobre as Marcas do Não-Eu”, em que ele ensinou as doutrinas essenciais do "não-eu", ou seja, de que não há uma substância simples, pura e permanente que tenha sua própria existência substancial e independente, análoga à doutrina da alma nas tradições ocidentais ou ao ātman no Hinduísmo. De fato, a doutrina do não-eu anātman é uma reação à ênfase hinduísta. Relacionada a esta doutrina do "não eu" está também a importante doutrina da pratītyasamutpāda, “originação dependente”. Também nos é ensinada a doutrina da impermanência de todas as coisas. O único "alguma coisa" - ou isso é um nada? - que evita a anītya (impermanência) e que temos como objetivo é o nirvāṇa em que evitamos a roda do sofrimento, que é a condição de todas as realidades existentes. As etapas de santificação que elevam um homem em direção ao nirvāṇa foram resumidas da seguinte forma:

A transição existencial de pessoa comum (prihagjana) à experiência do nirvāna pode ser vivenciada em várias etapas. A primeira etapa é tornar-se um membro da família dos personagens nobres espiritualmente eleitos (ārya pudgalas). Para isso, primeiramente, é preciso se preparar para iniciar as práticas que o tornarão um ārya pudgala. Até mesmo o início desta busca é significativo, que resulta na etapa de gotrabhū ou membro da família (de àryas). A partir daqui, dependendo do temperamento e da capacidade, um dos dois percursos está aberto: ou o seguidor na fé (śkaddhān-usārin), para aqueles com capacidades modestas, ou o seguidor do Dharma (Dharmānusārin), para aqueles de intelecto apurado. Ao adquirir progressivamente uma visão de cada uma das quatro nobres verdades, uma se torna, no auge do processo, uma srotāpanna ou streamwinner (aquele que vence as correntes do rio), a primeira classe das ārya pudgalas. Tendo abandonado totalmente a crença em si mesmo, as dúvidas sobre as Três Joias (isto é, Buda, Dharma, Samgha), a crença na eficácia dos rituais, garante-se ao streamwinner o esclarecimento dentro de mais uma vida. Avançando ainda mais, o adepto se torna um anāgāmin ou "o que não-retorna", assegurado de iluminação durante sua vida atual. Quando todas as qualidades negativas forem erradicadas e o adepto for puro em todos os aspectos, ele será capaz de realizar experiencialmente o nirvāna, tornando-se assim um arhant, e se estabelecendo como um verdadeiro santo no budismo. (PREBISH, 1975, p. 34).

\footnotetext{
${ }^{26}$ Este relato geralmente segue o excelente resumo da posição budista em C. Prebish (ed.). Buddhism: A Modem Perspective (Pensilvania, 1975), p. 29-35. Ver também E. Conze, Buddhism: Its Essence and Development (Londres, 1974; Nova York, 1965); R. Robinson, The Buddhist Religion (Califórnia, 1970); W. Rahula, What the Buddha Taught (Nova York, 1962); D. Rhys, Buddhism (Londres, 1914).
} 
Isso nos leva diretamente ao nirvāṇa, o objetivo de todo o empreendimento budista em todos os seus detalhes elaborados. Embora seja um assunto de opinião divergente ferozmente debatida entre os estudiosos do Budismo, para nossos propósitos parece justo dizer que o nirvāṇa: (1) é o reconhecimento de que a crença no "eu" fenomenal da existência mundana é uma ilusão; (2) é mais especialmente caracterizado pela extinção do "sofrimento", que é a característica predominante da realidade comum; (3) não é uma realidade condicional ou condicionada; (4) é, de alguma forma positiva, a obtenção de sabedoria única ou percepção da impermanência (anītya) de todas as coisas existentes; (5) não é um Ser; (6) é um estado ou condição, ou seja, no sentido de ser "Nirvanizado"; (7) não é um estado relacional de ser. ${ }^{27}$

A partir dessa estrutura complexa, vamos nos concentrar especialmente em duas características fundamentais do relato budista. Em primeiro lugar, a base de todo o sistema é a consciência do sofrimento no mundo e o objetivo do sistema é a extinção do sofrimento; em segundo lugar, a meta do nirvāṇa não é um estado relacional no qual o eu finito encontra um Ser transcendental salvador ou amoroso - Deus - mas sim um novo estado ontológico de ser (se esses termos não forem inapropriados). O fato de não haver nenhum tipo de encontro resulta do fato de que não existe um eu real e nenhum outro eu transcendental. Novamente, deve-se notar também que na doutrina budista não há vontade divina que desempenhe qualquer papel, pois não há divindade. Em vez disso, tem-se no lugar da vontade divina a estrita lei da causalidade ética, Karma, que está na raiz da cadeia causal da existência, reexistência ou reencarnação e libertação. ${ }^{28}$

O simples fato de confrontar este entendimento budista sobre a natureza das coisas com o Judaísmo já deveria, por si só, ser o suficiente para reforçar a tese de que o que o budista experimenta como nirvāṇa é diferente do que o judeu experimenta como devekuth. No entanto, vamos delinear isso de forma ainda mais clara. Inicialmente, quando o místico judeu expressa a sua especial devoção e

\footnotetext{
${ }^{27}$ Sobre o nirvāṇa, ver fontes citadas na nota 14.

${ }^{28}$ Além das fontes citadas acima na nota 26, ver N. Smart, Doctrine and Argument in Indian Philosophy (Londres, 1964); S. Radhakrishnan, Indian Philosophy (Londres, 1941); K. N. Jayatilleka, Early Buddhist Theory of Knowledge (Londres, 1963); D. Kalupahana, Causality: The Central Philosophy of Buddhism (Havaí, 1975); E. Conze, Buddhist Thought in India (Michigan, 1967); K. N. Jayatilleka, Survival and Karma in Buddhist Perspective (Kandy, 1969).
} 
meditação místicas, o kavvanot, ele o faz para purificar sua alma, ou seja, para remover a alma de seu aprisionamento no mundo material a fim de libertá-la para seu crescimento de ordem espiritual que culminará no devekuth, aderindo às emanações de Deus, os Sefirot. O místico budista, por outro lado, realiza suas práticas meditativas como parte integrante da busca mística budista, não para libertar a alma do corpo e purificá-la, mas para aniquilar o sofrimento, superando qualquer noção de "eu", sustentando que a própria noção de um substancial "eu" ou "alma" é a ilusão essencial que gera todo o processo de sofrimento. A literatura budista representa especificamente Buda como um crítico da crença em um "eu" permanente ou substancial (a doutrina hindu do àtman), criticando-a como sendo uma doutrina falsa, até mesmo perniciosa, e que, paradoxalmente, na medida em que encoraja o egoísmo na busca da própria felicidade eterna, torna a realização da própria felicidade uma impossibilidade.

Além de sua insistência na extinção do sofrimento por meio da eliminação do "self", o nirvāṇa também não é um estado relacional, ou seja, não é o encontro de duas individualidades ou realidades distintas que se unem em um abraço amoroso. O nirvāṇa é uma ausência de toda relação, toda personalidade, todo amor, todo sentimento, toda individualidade, toda identidade. O nirvāṇa é a conquista (se é que podemos usar esse termo, mas não temos outro melhor) da calma, da paz, da tranquilidade. Embora seja o banimento do cuidado ou ansiedade, da preocupação ou esforço, não é a criação de uma nova condição de encontro. O nirvāṇa não é "algo", nem contém ou permite a existência continuada de seres individuais ou de um grande Ser. Sua ontologia nem pode ser facilmente classificada como teísta, monística ou naturalista. No mundo das ideias religiosas, é o que mais se aproxima à lembrança de uma das observações de Wittgenstein feitas em outra conexão sobre "não ser algo nem um nada" (WITTGENSTEIN, 1958, sessão 304). Além disso, e isso não pode ser tomado ao pé da letra, é esta estrutura teórica da impermanência de toda a existência, o sofrimento resultante de todos os seres e as doutrinas do não-eu, meditação, etc. sobre as quais a vida e as metas dos Budista são usadas para construir o nirvāṇa. A compreensão budista da realidade gera todo o elaborado regime da prática budista, e é essa compreensão da realidade que 
define antecipadamente o que o místico budista está procurando e o que podemos dizer, a partir das evidências que ele encontra. É bizarro pensar que sua consciência pré-condicionada de como as coisas são e como encontrar libertação do sofrimento no nirvāṇa é alheia à experiência mística real do Budismo.

O que quer que seja de fato o nirvāṇa ou devekuth, na medida em que as palavras podem guardar qualquer significado em termos de investigações filosóficas, não há como descrever, e muito menos igualar, a experiência do nirvāṇa e do devekuth com base em evidências. Não há nenhuma maneira inteligível de alguém poder legitimamente argumentar que uma "não experiência" de calma "vazia" é a mesma experiência do que a de um relacionamento intenso, amoroso e íntimo entre duas personalidades substanciais, uma das quais é concebida como o Deus pessoal da religião ocidental e tudo o que isso implica. A perda do eu não é equivalente à descoberta do outro, especialmente quando este outro é concebido como o Deus da tradição judaica. Para enfatizar uma questão chave: a mística judaica é especialmente tocada pelo imaginário do amor, mesmo incluindo imagens sexuais muito pronunciadas, que são usadas para expressar todo tipo de "relações" relevantes para a mente cabalista. Este aspecto está totalmente ausente do Budismo primitivo indiano que iguala a sexualidade ao desejo e vê o desejo como o elemento básico que causa sofrimento e que deve ser superado no nirvāṇa. Minha intenção não é de avaliar, nem as alegações de verdade das experiências buscadas e relatadas no Judaísmo e no Budismo etc., nem presumir ou classificá-las em termos de melhor ou pior como Otto e Zaehner, por exemplo, o fazem de forma bastante arbitrária, ou ainda como faz também D. T. Suzuki, que rechaça os dogmatismos em favor da superioridade do Zen Budismo. O que eu pretendo tão somente é demostrar que existe apenas uma clara conexão causal entre a estrutura religiosa e social que se traz à experiência e a natureza da própria experiência religiosa.

Uma outra questão lógica precisa ser levantada. Refiro-me à minha observação inicial no parágrafo anterior de que, se as palavras significam alguma coisa, minha posição parece ser a única razoável a ser adotada. Muitos estudantes de mística podem ver esta observação como uma "escotilha de fuga" para evitar minha conclusão. Afinal, eles podem argumentar que todos os místicos temem o 
uso da linguagem para descrever sua experiência, e muitos se opõem absolutamente ao seu emprego, argumentando ser uma forma de "Eu não quero dizer o que eu digo e não digo o que eu quero dizer". Além disso, estamos certos de que seremos lembrados da conhecida propensão mística para o paradoxo e a inefabilidade como relevantes neste ponto. No entanto, essa "fuga" não é uma fuga em absoluto. Ela não fornece a saída desejada porque não percebe que, se o místico não quer dizer o que diz, e que suas palavras não têm qualquer significado literal, então não só é impossível estabelecer minha visão pluralista, mas como também é logicamente impossível estabelecer qualquer visão. Se nenhuma das afirmações dos místicos tem qualquer significado literal, então elas não podem servir como dados para qualquer posição, nem minha, e certamente nem a visão de que todas as experiências místicas são iguais, ou redutíveis a uma pequena classe de categorias fenomenológicas.

Lancemos um pouco mais de luz sobre essa questão fazendo apenas um pequeno passo marginal no estudo da mística, introduzindo uma outra tradição, o Cristianismo, que parece próxima ao Judaísmo, mas que, de fato, introduz novos elementos que são claramente o reflexo de um padrão teórico maior que molda a consciência mística do místico cristão. O espaço nos impede de expor as forças em ação nas tradições cristãs nos mesmos detalhes que temos para o Judaísmo e o Budismo, mas consideremos este um elemento essencial. Na mística cristã temos dois tipos de experiência mística, o tipo de experiência não absortiva que lembra a mística judaica e sua doutrina do devekuth, embora ainda com uma diferença, e o tipo absortiva (ou unitiva) no qual o objetivo buscado e a experiência alcançada é uma transcendência da distinção entre a individualidade e Deus e a absorção da individualidade em Deus em uma unidade abrangente. Este tipo absortivo é certamente um tipo comum de experiência mística cristã e é o que os estudantes da mística frequentemente, embora talvez erroneamente, consideram o paradigma da mística cristã. O grande místico flamengo, John Ruysbroeck (1293-1381), é assim capaz de expressar sua experiência na fascinante expressão “Alimentar-se e ser alimentado! Isto é união!... Como seu desejo é sem medida, ser devorado por ele não me surpreende muito” (RUYSBROECK apud UNDERHILL, 1911, p. 425). Isso é, de forma mais extrema, o que outros chamaram de perda de si no "oceano pacífico” 
de Deus, ou o que Eckhart se refere quando escreve: "Se eu devo conhecer a Deus diretamente, devo me tornar completamente ele e ele a mim: para que esse ele e esse eu se tornem apenas um eu" (ECKHART, 1903, p.122). O que permite, e talvez até encoraje, esta mística unitiva e absorvente do divino "Ele" e do finito "eu", que encontrei na mística cristã, embora ausente de sua contraparte judaica, é, creio eu, a influência formativa da teologia encarnatória essencial do Cristianismo que se baseia numa mistura de elementos humanos e divinos na pessoa de Jesus que está fora dos limites da consciência judaica. Assim, um elemento essencial do modelo de espiritualidade cristã é uma interpenetração divino-humana em nível ontológico que permite uma unidade do divino e do humano que o Judaísmo descarta. Essencial aqui também é a influência neoplatônica no pensamento cristão, especialmente para a mística cristã representada pelo maior de todos os místicos neoplatônicos, Plotino. ${ }^{29}$ Além disso, classificar esta unio mystica do místico cristão, ou melhor, de alguns místicos cristãos, não é uma tarefa tão fácil como julgou a maioria dos pesquisadores. A dificuldade surge porque a união com o divino, quando a divindade é entendida em termos cristológicos e encarnacionais, não é equiparável com (a) a experiência dualista do devekuth; (b) a experiência do não $E u$, não Deus, não relacional do nirvāṇa, (c) a mística naturalista como a de Richard Jefferies; (d) a mística não absortiva dos místicos não judeus cujas experiências diferem das do devekuth; ou mesmo (e) a mística absortiva que superficialmente se aproxima da Advaita.

Deve-se notar também que mesmo a dicotomia absortiva/não absortiva em ação na mística cristã, que que a princípio parece contradizer o enraizamento contextual da experiência mística, de fato a apoia. Os místicos cristãos unitivos são invariavelmente aqueles como Eckhart, Tauler e Suso, que foram educados em Plotino, Dionísio o Areopagita e Agostinho, ou seja, a forte corrente neoplatônica na história intelectual cristã. O Livro VI das Enéadas de Plotino fornece a inspiração para essa conceituação de ascensão final da alma à unidade ( $\tilde{v} v \omega \sigma \iota \varsigma)$ com o Bem. Plotino o descreve como uma absorção final inefável do Eu de volta ao

\footnotetext{
${ }^{29}$ Para mais informações sobre Plotino, veja A. H. Armstrong, Plotinus (Londres, 1953); W. R. Inge, The Philosophy of Plotinus, 2 v. (Londres, 1918); E. Underhill, Mysticism (Londres, 1911); A. H. Armstrong, "Plotinus", in A. H. Armstrong (ed.), Cambridge History of Later Greek and Early Medieval Philosophy (Cambridge, 1967), p. 195-271; E. Brehier, La Philosophie de Plotin (Paris, 1961); J. M. Rist, Plotinus: The Road to Reality (Cambridge, 1967). Este trabalho também inclui uma bibliografia completa para pesquisas posteriores.
} 
Um absoluto perfeito que transcende yucń ou vou/j; de volta ao Um que existe:

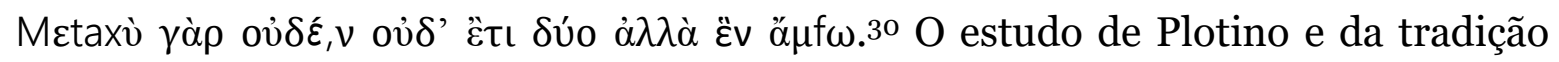
mística neoplatônica moldou o "olhar mental” do místico para que sua experiência se conformasse com ele. Pensar que o místico "unitivo" meramente descreve sua experiência dessa forma é distorcer a situação que deu origem à própria experiência e a seu relato. Assim, por exemplo, creditar seriamente que Agostinho não teve a experiência unitiva descrita em suas Confissões (Livro 9), mas apenas usou essa linguagem, é injustificado por pelo menos duas fortes razões: (1) certamente Agostinho não teria deliberadamente descrito sua experiência de forma equivocada; (2) a teoria do erro de descrição devido a pressões ortodoxas é insustentável no caso de Agostinho porque, de fato, o relato unitivo que ele dá está mais em conflito com a ortodoxia cristã do que uma descrição relacional teria sido, embora pareça que ele não tivesse consciência disso. A evidência para esta segunda contenda é o triste destino que alguns dos herdeiros "absortivos" de Agostinho encontraram nas mãos da Igreja. Por razões dogmáticas à parte, sejam elas dogmas filosóficos ou teológicos, não há boas evidências para negar que a experiência que Agostinho viveu tenha sido de caráter unitivo, como ele próprio a descreve como possuidora. Ao contrário, toda a sua vida foi uma longa preparação para tal experiência: “Tu nos fizeste para ti e nossos corações estão inquietos até que descansem em ti."

Se nos ativermos um pouco mais ao tema do contextualismo teológico e social, notaremos também uma outra característica importante que merece ser notada, bem como um estudo mais aprofundado. Em quase todas as tradições místicas, encontramos a necessidade de um professor ou guru que conduza o iniciante pelo “caminho”. Na tradição judaica, há uma forte aversão a autodidatas, tanto na tradição rabínica tradicional como mais ainda nos assuntos místicos. De fato, na tradição judaica, até a histórica calamidade da expulsão da Espanha, em 1492, exigiu-se uma nova abordagem radical ao místico, a sabedoria mística era sempre mantida muito próxima a seus devotos e era ensinada apenas em pequenos círculos a alguns poucos. Havia um constante receio de que este conhecimento, se

\footnotetext{
${ }^{30}$ Plotinus, Enneads, VI, 7:34 em Creuzer (ed.), Plotini Opera Omnia (Oxford, 1835).
} 
obtido pelos iletrados sem a orientação de um professor, pudesse levar ao antinomianismo e à heresia, como de fato aconteceu no movimento pseudomessiânico do século XVII conhecido como Sabataísmo ${ }^{31}{ }^{32}$ e no movimento pseudomessiânico do século XVIII conhecido como Frankismo33 34. Como consequência, os místicos judeus mostram uma estrita conformidade de fundo ideológico, de experiência compartilhada e de reflexão teológica. Esta característica é pronunciada na mística judaica, inclusive, por causa da suposta capacidade dos místicos judeus de escapar de um solipsismo místico por meio da linguagem "pública” da Torá, a qual serviu como um léxico místico nos círculos místicos judaicos e que também explica sua eventual, e altamente estruturada, natureza sistêmica, paradigmaticamente sustentada nas escolas Zoharicas35 e Luriânicas ${ }^{36}$. A menção da "escola" Luriânica é especialmente digna de nota porque reforça de forma demonstrável a natureza compartilhada, ensinada e comunitária desta teoria mística que surgiu na cidade de Safed $^{37}$ no noroeste de Israel, no século XVI. O desenvolvimento da mística Luriânica no movimento místico de massa em torno do pseudomessias Sabbatai Zevi, no século XVII, é também uma evidência de peso a ser considerada.

Na tradição budista, também se encontra a mesma ênfase em ser guiado ao longo do caminho em direção a nirvāṇa por um mestre qualificado. Somente um Buda alcança a autoiluminação, todos os outros devem ser ajudados para este fim. Ninguém menos do que o falecido Richard Robinson argumentou: "Toda forma de Budismo tem sustentado que é preciso contar com um guia” (ROBINSON, 1970, p.33). Também aqui se vê não apenas a importância de um professor qualificado ou bhikșu, mas também como a insistência na instrução adequada cresceu até se

\footnotetext{
${ }^{31}$ Sobre a fascinante história do Sabacianismo ver G. Scholem, Sabbatai Sevi (Princeton, 1973). Para um breve resumo da pesquisa de Scholem, ver cap. 8 de sua obra Major Trends in Jewish Mysticism (Nova York, 1954) e em Kabbalah (Nova York, 1974).

${ }^{32} \mathrm{NT}$ - Essa corrente de pensamento é também traduzida para o português como Sabatianismo

${ }^{33}$ Sobre o movimento Frankista, ver G. Scholem, Major Trends, cap. 8.

${ }^{34} \mathrm{NT}$ - Não confundir Frankismo - com o " $\mathrm{k}$ " no nome - com Franquismo: modalidade de fascismo praticada na Espanha que faz referência à figura do general Francisco Franco (1892-1975).

${ }^{35}$ Para mais detalhes sobre o sistema Zoharico, veja a Kabbalah de G. Scholem (inclui uma bibliografia completa para mais pesquisas); e sua obra On The Kabbalah and Its Symbolism (Nova York, 1965). Há também uma tradução da maior parte do Zohar em inglês por H. Sperling e M. Simon (Londres, 1931-4), 5 v.

${ }^{36}$ Sobre a Cabala Luriânica, ver G. Scholem, Major Trends, cap. 7; ver também as seções relevantes da obra Kabbalah de Scholem.

${ }^{37}$ Sobre a escola mística de Safed, que incluía Isaac Luria, Moses Cordovero e Joseph Karo, entre outros, ver S. Schechter, "Safed in the Sixteenth Century" em sua obra Studies in Judaism, 2a série (Filadélfia, 1908), p. 202-306. Ver também R. J.Z. Werblowsky, Joseph Karo (Oxford, 1962).
} 
tornar a instituição difundida do monaquismo budista ${ }^{3}$, com toda a sua rigorosa disciplina e compromissos ideológicos. E essas ênfases, é claro, não são exclusivas do Budismo, sendo a instituição de um mestre guru encontrada em todas as tradições orientais, como, por exemplo, o Hinduísmo especialmente em sua variante Tântrica, e o Zen. A tradição Zen é altamente esclarecedora aqui, pois embora tenha feito da espontaneidade a grande virtude em alcançar o satori, esta espontaneidade foi alcançada através do papel mediador que o mestre Zen desempenhou na "iluminação" de seus discípulos. Não somente esses mestres foram considerados os paradigmas dessa prática a serem imitados por seus discípulos, mas eles se tornaram até mesmo os objetos da meditação Zen para seus discípulos. Ainda mais importante, é o mestre Zen, através dos koans aparentemente sem sentido que coloca seus discípulos em meditação, bem como no propositado maltrato físico e mental a que submete seus alunos, que destrói as ilusões nas quais o discípulo está preso e que o impedem de alcançar o satori. $\mathrm{O}$ mestre induz no discípulo a condição de "enfermidade Zen" que permite que o discípulo rompa os laços da experiência condicional e encontre a realidade como ela realmente é, em sua "Talidade” (suchness) NT.39

Uma vez mais, esta vertente da conjuntura mística é fortemente concentrada na história do Sufismo, que desenvolveu em uma tradição amplamente difundida e bastante refinada nas suas escolas, apoiando o fiel do salak aț-tariq ("viajando pelo Caminho"). A essência destas ordens místicas, muitas vezes centradas em mosteiros Sufistas conhecidos como khānaqāhs, que consistiam na relação formal de mestre e discípulo, de murshid e murid, baseada na ideologia que, embora cada homem, potencialmente, possuísse de forma latente a capacidade de unir-se com Alá na união extática (fana), esta capacidade só poderia ser alcançada com a ajuda de um mestre qualificado (exceto no caso de uma pequena elite espiritual ou eleito conhecido como khawāsș ou Șúfiyya a quem Alá concedeu um favor especial). Seguir a tariqa (“o caminho"), era um método prático para o discípulo subir por

\footnotetext{
${ }^{38}$ Sobre o monaquismo budista ver C. Prebish, Buddhist Monastic Orders (Pensilvania, 1975). Ver também N. Dutt, Early Monastic Buddhism (Calcutá, 1960); S. Dutt, Buddhist Monks and Monasteries of India (Londres, 1962); I. B. Horner, trans., The Book of Discipline, 6 v. (Londres, 1938-66); G. De, Democracy in Early Buddhist Sangha (Calcutá, 1955).

${ }^{39}$ Para mais informações sobre Zen Budismo, veja Shoku Watanabe, Japanese Buddhism (Tokyo, 1968); H. Dumoulin, A History of Zen Buddhism (Londres e Nova York, 1963); D. T. Suzuki, Introduction to Zen Buddhism (Nova lorque, 1964; Londres, 1969); J. Kitagawa, Religion in Japanese History (Nova York, 1966); D. T. Suzuki, Essays in Zen Buddhism, 3 v. (Londres, 1949-53).
} 
uma sucessão de etapas (maqāmāt) culminando na experiência de fana - unidade em Alá. A tariqa consiste em orações fixas, exercícios extenuantes, outros variados atos litúrgicos e penitenciais, jejuns, retiros, vigílias e afins. Esse procedimento altamente estruturado prepara o discípulo para sua experiência, ou seja, o "prepara" no sentido de colocá-lo no quadro de consciência especificamente sufi, tanto ideológica quanto existencialmente, para sua experiência extática, cuja forma também foi antecipada. ${ }^{40}$ Da mesma forma, a esmagadora maioria dos místicos cristãos é encontrada nos mosteiros e ordens sagradas com suas vidas centradas em torno da castidade, e "boas obras" e um regime extremamente rigoroso de oração. Fritz Staal também nos lembrou recentemente que o professor indiano mexicano, Don Juan, foi essencial para as experiências notáveis de Castaneda, independentemente do que se pense a respeito das experiências de Castaneda. ${ }^{41}$

Em todos esses casos, alguém pode se perguntar "o que ensina um guru". A resposta é que ele ensina um caminho específico e uma meta específica; seus alunos o seguem através do caminho principal porque querem alcançar o fim. Assim, para dar um exemplo, o "fiel" budista chega a seu mestre (e à Sangha) e segue suas meditações e práticas de yoga prescritas para atingir aquele estado em que o sofrimento é aniquilado e a noção errônea do eu, conhecida como a doutrina de anātmavada, está completamente superada. Alternativamente, o "fiel" hindu segue lealmente as instruções de seus gurus porque deseja afirmar a natureza última de seu eu e sua relação com o eu universal, conhecida como atmavada. Mais uma vez, o Murid é leal à disciplina rigorosa de seu Murshid porque ele busca fundir sua alma com o Deus pessoal do Islã; enquanto o Cabalista Judeu pratica seu regime de oração e ascetismo para encontrar devekuth com o ser emanado por extensão de Deus manifestado nas Sefirot. O guru budista não ensina o que o guru hindu ensina, embora a associação superficial do termo confunda os incautos. $\mathrm{O}$ Murshid não ensina o que o Cabalista ensina, nem tampouco Teresa de Ávila

\footnotetext{
${ }^{40}$ Ver sobre o monaquismo sufista e as ordens sufistas, o excelente trabalho de J. Spencer Trimingham intitulado Sufi Orders (Oxford, 1971). Ver também A. Schimmel, Mystical Dimensions of Islam (Carolina do Norte, 1975); R. Gramlich, Die schutischen Derwischorden Persiens (Wiesbaden, 1965).

${ }^{41}$ Ver F. Staal, Exploring Mysticism (Londres, 1975).
} 
ensina São João da Cruz da mesma forma que Don Juan42 ou o Mestre Taoísta. A prova decisiva disso é encontrada não apenas em um exame atento dos respectivos "ensinamentos" dos vários professores, mas também no espírito polêmico manifestado por muitos, senão a maioria, dos mestres místicos. O Shankara não hesita em entrar em polêmicas acaloradas com seus oponentes budistas sobre o significado da experiência final, entendida por ele de uma forma monística não pessoal, ou novamente com seus colegas hindus de mentalidade mais teísta - e de dizer que eles estão errados! Eles não entendem! Eles não têm a melhor experiência! - somente ele e seus alunos encontram a experiência definitiva, porque somente eles estão devidamente equipados para encontrá-la. Alternativamente, na tradição cristã encontramos, por exemplo, Ruysbroeck preparado para criticar aqueles místicos para os quais a experiência mística não envolve imperativos morais como inferiores, enquanto os zen-budistas têm testes e regras para investigar se uma pessoa realmente atingiu o satori ou o nirvāṇa.43 Por exemplo, o grande mestre zen Hakuin registra em sua autobiografia, o Itsu-madegusa, que, após uma experiência precoce, ele foi convencido de que havia alcançado a condição de iluminação e partiu para relatar esta boa notícia a Etan, o idoso eremita de Shojuan. Após ser interrogado pelo Mestre, Hakuin ainda estava em falta e foi repreendido com o epíteto: "Pobre filho do diabo em uma masmorra escura”. Após um estudo mais aprofundado, Hakuin relata que "a iluminação passou por minha mente", e quando ele foi testado novamente por Etan "o mestre agora acariciou minhas costas com seu leque" (isto é, com um sinal de aprovação).44 Também deve ser observado que os clássicos dos místicos não falam sobre a abstração "mística"; falam apenas sobre sua tradição, seu "caminho", seu "objetivo": não reconhecem a legitimidade de nenhum outro. Os tons ecumênicos

\footnotetext{
${ }^{42}$ Este é o nome do professor mexicano de índios Carlos Castaneda. Veja a trilogia de Castaneda Teachings of Don Juan: Um Way oh Knowlodge (Berkeley, 1970); A Separate Reality: Further Conversations with Don Juan (Nova York, 1971); e Journey to Ixtlan (Nova York, 1972).

${ }^{43}$ Para fontes Zen sobre "testes" nirvāna ou satori, veja a discussão do koan Zen e outros procedimentos que acontecem entre um Mestre Zen e seus discípulos. Algumas discussões sobre este assunto podem ser encontradas, por exemplo, em H. Dumoulin, $A$ History of Zen Buddhism (Londres e Nova York, 1963); P. Kapleau, The Three Pillars of Zen (Boston, 1967); Guy Welbon, The Buddhist Nirvana and its Western Interpreters (Chicago, 1968); E. Lamotte, Histoire du Buddhisme indien (Paris, 1967); D. T. Suzuki, Introduction to Zen Buddhism (Kyoto, 1934); Zen Comments on the Mumonkan (Nova York, 1974).

${ }^{44}$ Para detalhes, veja a autobiografia de Hakuin, "The Itsu-made-gusa" em Hakuin Oshō Zenshū, I, p. $149-230$ (Tóquio, 1935). Veja também seu tratamento mais amplo deste tópico em seu "Orategama" em Hakuin Oshō Zenshū, V, p. 105-246. Veja também a crônica da vida de Hakuin preparada por seu discípulo Enji Torei, intitulada 'Shinki - dokumyo Zenzi nempuingyokaku' (Crônica de Hakuin) em Hakuin Oshō Zenshū. I. p. 1-78. Para uma breve e útil discussão sobre estes eventos, ver H. Dumoulin, A History of Zen Buddhism (Londres e Nova York, 1963), p. 247-255.
} 
associados à mística vêm principalmente de não místicos de safra recente para atingir os seus próprios fins.

Embora tenhamos acabado de iniciar a descrição e o estudo da enorme, até mesmo desconcertante, variedade de detalhes específicos que o estudo técnico de tradições místicas específicas revela, acredito que está suficientemente demonstrado que não será necessário argumentar que as evidências empíricas indicam que todas as experiências místicas são as mesmas ou que tais experiências são contextualmente indeterminadas ou subdeterminadas. As evidências que consideramos até este ponto, de fato, apontam na direção oposta: ou seja, a experiência mística é "superdeterminada" por seu meio sociorreligioso: como resultado de seu processo de aculturação intelectual em seu sentido mais amplo, e como resultado de seu processo de aculturação intelectual, o místico traz para sua experiência um mundo de conceitos, imagens, símbolos e valores que moldam, assim como colorem, a experiência que ele eventualmente e de fato tem.

\section{PARTE III}

Passemos agora a alguns dos mais curiosos problemas lógico-filosóficos inerentes ao estudo da mística que reforçam a tese contextual que está sendo discutida aqui.

O fator inicial que precisa ser considerado é o significado ou os significados dos termos usados pelos místicos para descrever ou interpretar suas experiências, pois é este fator que ilude alguns como Underhill, Otto, Stace, Bucke, Arberry e Zaehner, entre outros, que pensam que todos os místicos estão se referindo à mesma experiência ou a um pequeno número de experiências semelhantes. Por exemplo, Stace (STACE, 1961, p. 106-107), em sua argumentação pela existência de um "núcleo universal” comum a todas as experiências místicas, compara, entre outras, a experiência cristã de Eckhart, a experiência do Cabalista judeu de devekuth, e a doutrina budista de sunyata ou do Vazio. Em cada caso, Stace acredita que o uso de uma linguagem aparentemente semelhante reflete uma experiência "central" subjacente. Por exemplo, ele sustenta que o "fato" de que em 
cada um desses relatos místicos é afirmado que não há conteúdo empírico na experiência (STACE, 1961, p. 109), e que todos esses místicos parecem descrever sua experiência como sendo não espacial, não temporal, além da linguagem inefável, paradoxal, sublime e alegre entre outros traços, e que é uma clara evidência para sua visão a respeito da existência de um "núcleo comum". Stace, entretanto, e os outros que adotam um procedimento semelhante e chegam a resultados semelhantes estão aqui sendo enganados por uma semântica superficial dos relatos místicos estudados por eles. Isso significa dizer que o que parecem soar como descrições semelhantes não são e não indicam ser a mesma experiência, e elas não são, porque a linguagem em si é contextual e as palavras têm seu significado apenas em contextos específicos. As mesmas palavras - bela, sublime, realidade última, inefável, paradoxal, alegre, transcendem todo conteúdo empírico etc. - podem se aplicar e têm sido aplicadas a mais de um objeto. Sua mera presença não garante nada; nem a natureza da experiência, nem a natureza do referencial, nem tão pouco a comparabilidade de várias reivindicações que têm sido asseguradas apenas por esta presença verbal aparentemente comum. Consideremos o seguinte exercício. Um judeu poderia usar todos esses termos para se referir a sua experiência de devekuth com o Ser Absoluto moral e pessoal que ele chama de Deus. Ao mesmo tempo, o budista poderia usar todas essas frases para se referir à ausência de todo ser no nirvāṇa, enquanto o hindu poderia usá-las para se referir à sua experiência de absorção no Brahman Absoluto Impessoal. Novamente, o taoísta poderia usar estes termos, assim como Plotino ou o místico da natureza ao se referir à Natureza. Podemos expressar isto claramente através do seguinte exemplo. Considere a ambiguidade da proposta:

$\mathrm{X}$ transcende todo conteúdo empírico, está além do espaço e do tempo, é a realidade última, dá uma sensação de alegria, é sagrado, só pode ser expresso em paradoxos e é realmente inefável.

Onde $\mathrm{X}$ pode ser substituído por vários candidatos, radicalmente diferentes e mutuamente exclusivos, como, por exemplo, Deus, Brahman, nirvāṇa e a Natureza.

O que emerge claramente desse argumento é a consciência de que a escolha de descrições da experiência mística longe de seu contexto total não fornece 
fundamentos para sua comparabilidade, mas, ao invés disso, separa todos os fundamentos de sua inteligibilidade, pois esvazia as frases, termos e descrições escolhidas de significado definido. Este problema lógico-semântico atormenta todas as tentativas que fizeram vários estudiosos, a partir de William James, para fornecer uma descrição fenomenológica comum da experiência mística. O fato é que essas listas de elementos supostamente comuns não somente sempre reduzem a variedade real de experiências díspares para se adequar a uma teoria específica (em cada caso o contexto dos termos utilizados é o próprio sistema específico do investigador que varia as listas de acordo e demonstra, quando nada mais, que o material pode ser arranjado de diferentes maneiras, de acordo com propósitos ulteriores alternativos), mas também acabam sendo de pouca ajuda na compreensão da experiência mística porque são tão amplos a ponto de se adequarem a qualquer uma das várias experiências mutuamente exclusivas. Considere, por exemplo, a lista de James em sua famosa As Variedades da Experiência Religiosa (JAMES, 1958, p. 292). James sugere quatro características comuns da experiência mística: (1) inefabilidade; (2) qualidade noética; (3) transitoriedade; e (4) passividade. Sem uma revisão muito detalhada, consideremos como modelos os termos "inefabilidade" e "noesis", que o próprio James considerava os mais importantes. A "inefabilidade" James define corretamente como uma experiência ou assunto que "desafia a expressão, que não se pode fazer por palavras nenhum relato adequado do seu conteúdo", e continua concluindo como consequência que "se segue que a sua qualidade precisa ser experimentada diretamente; não pode ser comunicada nem transferida a outros" (JAMES, 1958, p. 293). Embora uma descrição precisa da "inefabilidade", a definição de James não é a base sobre a qual se podem comparar experiências nem concluir que experiências diferentes têm algo em comum no sentido de que ambas são instâncias de situações iguais ou similares ou reflexo de experiência com um "objeto" ou realidade comum. Embora se diga que duas ou mais experiências são "inefáveis", o termo "inefáveis" pode logicamente caber em muitas experiências disjuntivas e incomparáveis. Isso significa dizer que, um ateu pode sentir uma sensação de pavor perante o absurdo do cosmos que ele rotula de inefável, enquanto um teísta pode experimentar Deus de uma forma que ele também insiste 
ser inefável. Assim, na obra I and Thou, Buber descreve como encontro dialógico com Deus, o Tu Absoluto, como inefável, cujo "significado em si não pode ser comunicado ou expresso" (BUBER, 1970, p. 159), enquanto Kafka, cujas histórias brilhantes e assombrosas também sugerem a inefabilidade da existência, não pretende tal encontro45, nem suas histórias refletem qualquer fé na existência de um Tu Absoluto. É, portanto, absurdo tentar argumentar que, porque tanto Buber como Kafka veem suas respectivas experiências como inefáveis, a experiência dialógica da relação de Buber do Eu com o Tu Absoluto é a mesma ou semelhante à experiência das almas perdidas em $O$ Castelo de Kafka. Onde um encontra "significado confirmado"46, o outro encontra "vazio". Mais uma vez o inefável nirvāṇa não é o inefável Allah do Sufismo, nem tão pouco o inefável Tao do Taoísmo. A ontologia ou realidade de Brahman/Atman que está "além de toda expressão" nos Mandukya Upanishads não é a "inefabilidade” encontrada na experiência cristã de Eckhart. "Eles eram tolos, porque a verdade oculta que viam em Deus, o mistério que lá encontraram, era inefável”. Ainda menos comparável é o Deus "inefável” de Eckhart, como a realidade que está sendo apontada, mas ainda assim mantida "inefável” no seguinte koan Zen: Perguntou-se a um mestre Zen: "O que é o Buda?” ao qual respondeu (de maneira bastante típica ao Zen), "Esterco $\sec 47 " 48$.

Vamos também analisar de forma breve a ênfase de James na universalidade da "noesis" como um elemento distintivo e comparável da experiência mística. James define esta característica da seguinte forma: "Conquanto muito semelhantes a estados de sentimento, os estados místicos parecem ser também, para os que os experimentam, estados de conhecimento" (JAMES, 1958, p. 293), e ele continua explicando, "estados de visão interior dirigida a profundezas da verdade não sondadas pelo intelecto discursivo”. James captou algo importante ao chamar a atenção para o elemento noético na experiência mística, mas não é, no entanto, um

\footnotetext{
${ }^{45}$ Em Kafka, veja suas Collected Complete Stories, N. Glatzer (ed.) (Nova York, 1971). Veja também seus contos clássicos, The Castle, The Penal Colony, e The Trial.

${ }^{46}$ Ver M. Buber, I and Thou, p. 158-159.

${ }^{47}$ NT - O texto original em inglês diz que Buda é "a dried shit stick" que literalmente significa "uma vara de merda seca", que era, à época, o instrumento utilizado para limpeza íntima das fezes, tanto que alguns traduzem essa resposta para o português como "um pedaço de papel higiênico usado".

${ }^{48}$ De R. H. Blyth, Zen and Zen Classics, v. I (Japão, 1960), p. 114-115. Citado por Ben-Ami Scharfstein Mystical Experience, p. 168.
} 
elemento que proporciona a uniformidade desejada. Deve-se considerar, para começar, a variedade das diferentes reivindicações de conhecimento que poderiam se encaixar na definição de James e que seus próprios exemplos reconhecem, ou seja, que esta característica tem sido reivindicada para experiências tão diferentes como aquelas que poderiam ser classificadas como estéticas, éticas, naturais, religiosas e místicas. Argumentar, como faz James, que todas as experiências são as mesmas porque cada uma dessas experiências afirma fornecer "estados de visão interior dirigida a profundezas da verdade não sondadas pelo intelecto discursivo", falha em reconhecer que podem ser "sondadas" tanto as variedades de "visões interiores" que se podem ter sobre as "profundezas da verdade", quanto a variedade de "verdades" que podem ser espreitadas nessas profundezas. As diferentes reivindicações feitas para tal conhecimento da "verdade" são espantosas, indo das especulações pitagóricas ao vodu, animismo e totemismo, à teosofia de Madame Blavatsky e à philosophia perennis de Huxley e Ramakrishna, para não falar da variedade de religiões mais tradicionais.

Comparem-se os dois exemplos contemporâneos de Castaneda e Suzuki. A "verdade" que Dom Juan revela a Castaneda através do uso da planta alucinógena do peiote tem pouca ou nenhuma semelhança com a "verdade" do satori exaltada pelo mestre Zen. A qualidade "noética" destas duas experiências não é obviamente a base para sua comparabilidade ou equiparação.

Para dar mais amplitude a este ponto, considere também a tentativa de W. T. Stace de construir uma lista de características místicas comuns que atravessam os limites culturais ou temporais da experiência mística. Stace primeiro lista como segue as características do que ele considera os dois tipos básicos de experiência mística (STACE, 1961, p. 131-132): 
CARACTERÍSTICAS COMUNS DE

EXPERIÊNCIAS MÍSTICAS

EXTROVERTIDAS

1. A Visão Unificadora - todas as coisas são uma;

2. A apreensão mais concreta do Um como subjetividade interior, ou vida, em todas as coisas;

3. Sentido de objetividade ou realidade;

4. Bem-aventurança, paz, etc.

5. Sensação de sagrado, sagrado ou divino

6. Paradoxalidade;

7. Alegado pelos místicos como inefável.
CARACTERÍSTICAS COMUNS DE

EXPERIÊNCIAS MÍSTICAS

INTROVERTIDAS

1. A Consciência Unitária; o Um, o Vazio; consciência pura;

2. Não espacial, não temporal;

3. Sentido de objetividade ou realidade;

4. Bem-aventurança, paz, etc.

5 Sensação do sagrado, sagrado ou divino;

6. Paradoxalidade;

7 Alegado pelos místicos como inefável.

Ele conclui então que, "as características 3, 4, 5, 6, 7 são idênticas nas duas listas e são, portanto, características comuns universais da mística em todas as culturas, idades, religiões e civilizações do mundo" (STACE, 1961, p. 132). Diz ainda mais, e acrescenta uma palavra final sobre o assunto: "A experiência extrovertida, embora a reconheçamos como um tipo distinto, na realidade está em um nível inferior ao do tipo introvertido" (STACE, 1961, p. 132). Embora esta posição final reflita claramente o preconceito monista e introvertido de Stace, ela nos dá uma reivindicação direta a respeito das supostas características místicas comuns de Stace: "o senso de objetividade ou realidade”; "bem-aventurança, paz, etc."; "sentimento do sagrado, ou divino"; "paradoxalidade" e "inefabilidade". Tomemos o número 3 , “o sentido da objetividade ou da realidade" como nosso modelo para exame. Embora seja verdade que todos os místicos afirmam que sua experiência é uma experiência da realidade - na realidade com um " $R$ " maiúsculo esta afirmação aparentemente comum não fornece nenhuma base para a conclusão radical de Stace sobre as "características comuns universais da mística”. Isso é assim não porque os termos "objetividade" e "realidade" sejam tão notoriamente elusivos quanto sedutores. Todos os sistemas e todos os místicos tinham 
reivindicado a objetividade final e a Realidade descoberta, mas as reivindicações são mais frequentemente incompatíveis entre si. Por exemplo, enquanto a objetividade ou realidade (Realidade) em Platão e Neoplatonismo é encontrada no "mundo das ideias", estas características são encontradas em Deus na mística judaica e novamente no Tao, no nirvāṇa, e na Natureza, no Taoísmo, Budismo, e Richard Jefferies49 respectivamente. Parece claro que esses respectivos místicos não experimentam a mesma Realidade ou objetividade e, portanto, não é razoável supor que suas respectivas experiências de Realidade ou objetividade sejam semelhantes. Como presumivelmente poucos de meus leitores tiveram uma experiência mística, talvez este ponto possa ser reforçado pela comparação dos termos "Realidade", digamos, no Marxismo, onde a Realidade é equiparada ao econômico e material, como contra o freudianismo, no qual a Realidade é definida em termos psicológicos ou, alternativamente, no empirismo, no qual a Realidade é equivalente ao sensível ou o que é derivado do sensível, em comparação à "Realidade" idealista, que é ideacional e não sensível. A presença do termo "Realidade" não é garantia nem de uma experiência comum nem de uma nova linguagem e metafísica comuns.

Uma inspeção cuidadosa mostra que, enquanto as listas de supostas características fenomenológicas parecem ajudar a delinear o que é a experiência mística, e também a estabelecer o que une essas experiências aparentemente diferentes como uma classe de experiências semelhantes, tais listas, de fato, são tão gerais que, embora sirvam para excluir certos tipos de experiências como as que se encontram, para dar um exemplo bizarro, na contemplação do próprio umbigo e dizer que isso é uma experiência mística, elas permanecem tão gerais que não são suficientes para delinear o que é realmente a experiência mística, nem são, mais uma vez, sofisticadas no reconhecimento da base contextual da linguagem e, portanto, incapazes de ordenar o significado real dos relatórios místicos. A "intoxicação de Henry Suso com a imensurável abundância da Casa Divina ... inteiramente perdida em Deus [do Cristianismo]"50, nos Upanishads "sat [o que é]

\footnotetext{
${ }^{49}$ Para saber mais sobre a mística da natureza de Richard Jefferies, veja sua obra The Story of My Heart (Londres, 1912). Para uma breve discussão sobre a vida e o pensamento de Jefferies, veja R. C. Zaehner, Mysticism. Sacred and Profane, p. 45-49.

${ }^{50}$ Henry Suso, Little Book of the Eternal (Londres, 1953), p. 185.
} 
... é expressa na palavra satyam, o Real. Compreende todo este universo: Tu és todo este universo" ${ }^{1}$, assim como a “dimensão do nada” (ākincañ̃̃āyatana)52 do Budismo podem ser todas incluídas nessas amplas descrições fenomenológicas da "Realidade”, mas, pelas razões já aventadas, é claro que o Deus Cristão de Suso não é equivalente ao "vazio" budista, e que a experiência de entrar na Casa Divina não é equivalente a perder-se no "vazio" budista. Torna-se evidente na reflexão que diferentes entidades metafísicas podem ser "descritas" pelas mesmas frases se estas frases forem suficientemente indefinidas, assim como as frases descritivas muito gerais usadas em nossas listas fenomenológicas. Embora pareçam delinear fenômenos bastante concretos, estas listas não têm o poder de fornecer descrições definitivas de nenhum fenômeno discreto específico: nem a alegada experiência mística universal e comum, nem qualquer outra coisa53.

A menção de diferentes realidades ontológicas sendo cobertas pelo mesmo termo é uma questão que levanta sérias dificuldades de ordem lógica, semântica e metafísica. Considere, por exemplo, o uso do termo "vazio" que acaba de ser mencionado no contexto da "experiência do vazio" budista. Quando comparações são feitas, com base na presença desse termo sem investigação cuidadosa, surgem problemas intransponíveis. Isso porque é preciso perguntar desde o início sobre o uso preciso do termo. Ele está sendo usado como uma descrição subjetiva de uma experiência ou uma suposta descrição objetiva de um objeto ou estado ontológico objetivo do ser? Esta é a diferença entre usar o termo de uma forma análoga ao uso subjetivo de "felicidade", ou seja, "eu experimento a felicidade" em comparação com a afirmação objetiva (e objeto) “eu experimento Deus”. O problema da reificação, naturalmente, também entra em cena. Esta distinção já indica que o enunciado do termo "vazio" não é suficiente para assegurar o uso unívoco do termo. Mais uma vez, este uso incentiva a refletir sobre as afirmações ontológicas que se encontram abaixo e são correlatos necessários da linguagem. Mesmo concordando que em dois ou mais casos o termo "vazio" está sendo usado no sentido de uma referência ontológica objetiva, ainda não há certeza de que o termo

\footnotetext{
${ }^{51}$ Brihadāranyka Upanishad, 1:4:10.

${ }^{52}$ Veja o Samyutta Nikāya, IV:360.

${ }^{53}$ Uma discussão crítica completa dos problemas inerentes a uma variedade das mais importantes tipologias fenomenológicas da experiência mística aparecerá em meu próximo trabalho intitulado "Fenomenologia, Descrição e Experiência Mística".
} 
está sendo usado de forma sinônima. É preciso perguntar se as várias experiências do "vazio" são experiências semelhantes ou diferentes do mesmo fenômeno, ou seja, "vazio", ou experiências diferentes de fenômenos diferentes, ou seja, "vazio" é um termo que é usado para cobrir realidades ônticas alternativas. Neste último caso, que parece encaixar pelo menos um segmento substancial dos dados da experiência mística de forma mais adequada, a diferença entre casos é uma diferença entre o que é vivenciado, e não apenas como algo é vivenciado. A adequação deste segundo esquema, ou seja, que o termo é usado para cobrir diferentes "estados de coisas" ônticos, recomenda-se a si mesmo porque para sustentar que é apenas um caso de como se experimenta uma realidade comum, seria preciso ter uma lista suficientemente delimitadora de correspondentes e acordados que prediz que o objeto experimentado possuía em ambos (ou mais) casos que estão sendo comparados. Isso, entretanto, está ausente em pelo menos muitos, se não a maioria, dos casos. Situações mais concretas de uso nos ajudarão aqui. Stace, por exemplo, considera o uso do "vazio" como uma característica quase universal da experiência mística, que ele considera ser outro apoio valioso para sua tese de um "núcleo" universal. Assim, ele compara o uso do termo como encontrado em um conto Hassídico com aquele encontrado em outros lugares em relatórios místicos orientais e ocidentais. Infelizmente a comparação de Stace é superficial, se baseada na ignorância do contexto Hassídico-Cabalístico, o que dá ao termo seu significado peculiarmente Hassídico. O termo "vazio" ou "vacuidade" neste ambiente intelectual judeu não significa, como Stace erroneamente acredita, uma referência a uma experiência introvertida de unidade mística do tipo monística como é entendida por Stace (1961, p 133). Como ele trabalha a partir de traduções, e não dos textos originais hebraicos, não compreende que o termo neste contexto é uma tradução do termo Ayin que é usado na literatura cabalística como um nome de Deus relacionado a seus primeiros atos de autorrevelação a partir de seu mistério autônomo como Eyn Sof (Deus como Ele que está em Si mesmo) e ainda antes de sua manifestação como o primeiro Sefirah Keter. No final do século XIII, a Masoret ha-Berit entende que Ayin "é mais existente que todo o ser do 
mundo. Mas desde que é simples, e todas as coisas simples são complexas em comparação com a sua simplicidade, é chamado 'vazio' [Ayin]"54. Como Ayin, o “vazio", Deus, como o termo se destina a indicar, ainda está além de toda e qualquer compreensão humana da experiência. Como Ayin, Deus ainda está sozinho. Nenhuma experiência humana jamais alcança relação com esta dimensão da natureza de Deus. Os comentários de Stace sobre esta noção, portanto, podem ser vistos como um caso de eisegese 55 que está totalmente fora de contexto e sem qualquer significado nas fontes cabalísticas originais e no relato místico Hassídico.

Por outro lado, o termo "vazio" também é destacado nos textos budistas. O termo budista chinês e japonês $M u$ é usado, para "vazio" e "não ser", não é uma referência a Deus como ele é em si mesmo ou em seus primeiros estágios de autorrevelação, mas se refere à condição ontológica absoluta de vazio ou sūnyatā que transcende todo ser, toda predicação, toda substancialidade. E aqui, é claro, a compreensão do sūnyatā torna-se o tema de um debate feroz entre escolas de Budismo concorrentes, sendo especialmente importante para os Mahāyānistas. Mais uma vez, é frequente, mas a meu ver equivocado, argumentar-se que a tradição mística cristã de Dionísio, o Areopagita56, e seus herdeiros que falam do "vazio", como nichts (nada em alemão) na linguagem de Eckhart, é a mesma que a $M u$ budista, pois o místico cristão, como Eckhart, busca o renascimento de sua alma agora purificada através de sua imersão no Gottheit, enquanto o budista busca o sūnyatā como a transcendência ou a libertação de toda a individualidade. Observamos também que o conceito elusivo do "eu(self)", e obviamente central para essa discussão, precisa de um exame minucioso em seus contextos cristãos oriental e ocidental e budista, se quisermos que essas comparações façam sentido. Simplesmente acrescentar à lista de termos usados em todas as tradições do "eu (self)”, sem exploração e análise minuciosas de seu significado, é aumentar a

\footnotetext{
${ }^{54}$ Ver David ben Abraham ha-Lavan, Masoret ha-Berit, citado por G. Scholem, Kabbalah (Nova York, 1974), p. 95. Ver toda a discussão de Scholem sobre este termo em sua obra Kabbalah, p. 94-95.

${ }^{55}$ NT - Eisegesis, é um processo em que se faz a interpretação de um texto com base em ideias pré-concebidas de seus significados, portanto, Eisegesis é o que está sendo feito quando alguém interpreta a Bíblia de acordo com noções que nasceram fora da Bíblia.

${ }^{56}$ Para mais sobre Dionísio, o Areopagita, veja J. Vanneste, Le Mystere de Dieu (Bruxelas, 1959); E. Underhill, Mysticism (Londres, 1911); H. Koch, Pseudo-Dionysius Areopagita (Mainz, 1900); H. F. Muller. Dionysius, Proclus, Plotinus (Munster, 1918); I. P. Sheldon-Williams, "The Greek Christian Platonist Tradition" in The Cambridge History of Later Greek and Early Medieval Philosophy, ed. A. H. Armstrong (Cambridge, 1967), p. 457-472. Este trabalho inclui uma bibliografia para pesquisas adicionais.
} 
confusão respectiva para esclarecer, por exemplo, a noção de "vazio".57

Da mesma forma, Stace também argumenta que a mística islâmica manifesta características universais semelhantes àquelas encontradas no Budismo, Hinduísmo, Judaísmo e afins. No entanto, a atenção ao estado místico islâmico final de fana fi-Allah revelará que, por exemplo, não é o mesmo que o nirvāna, e, da mesma forma, quando o místico islâmico fala do "vazio" de sua experiência, ele não dá o mesmo significado que o Mestre chinês dá quando fala de $M u$, ou o Hinayanista e o Mahayanista quando falam de sūnyatā. Estar envolvido no "vazio" do fana não é apenas perder a identidade - a semelhança que Stace se apega para fazer sua comparação equivocada - mas também a baqa (lit. subsistência), vida eterna em Allah. No entanto, na doutrina budista não há entidade ou estado comparável ao baqa, assim como não há Deus ou ser semelhante a Deus no Budismo. É precisamente essa fusão com Allah no sentido de baqa que, por exemplo, o Sufi Abu Ali de Sind (apud, NICHOLSON, 1914, p.17) descreve quando fala sobre sua experiência de fana: "As criaturas estão sujeitas a "estados" mutáveis, mas o gnóstico não tem "estado", porque seus traços são apagados e sua essência aniquilada pela essência de outro, e seus traços são perdidos nos traços do outro."

Novamente, Baba Krihi de Shiraz (apud, NICHOLSON, 1914, p. 59) dá sentido preciso a esse uso islâmico de "vazio" quando discute sua experiência: "Mas quando olhei com os olhos de Allah - apenas Allah eu vi. Eu morri no vazio, desapareci e, eis que era o que vivia tudo - apenas Allah eu vi."

Em relação à confusão linguístico-ontológica que acabamos de discutir, há também uma questão lógica substancial a que nos referimos brevemente anteriormente e que agora exige uma discussão mais sustentada. Essa questão está relacionada à alegação de que a linguagem mística é negada por sua "inefabilidade" e por seu "paradoxo". Estas duas características são elementos padrão em todas as descrições fenomenológicas da experiência mística e são tomadas como base para sua comparabilidade; mas será que elas realmente apoiam essa posição? Esses elementos permitem logicamente a investigação sobre a possível identidade das

\footnotetext{
${ }^{57}$ Ver Masao Abe, "Non-Being and Mu" in Religious Studies 11, n. 2 (jun. 1975), p. 181-192. Ver também F. Sontag, "Freedom and God" in Religious Studies, 11, n. 4 (dez. 1975), p. 421-432.
} 
experiências místicas e sua tentativa de comparabilidade, especialmente sua alegada equivalência ou similaridade? O que me leva a fazer estas perguntas é o seguinte argumento: os termos "paradoxo" e "inefável” não funcionam como termos que nos informam sobre o contexto da experiência, ou qualquer dado “estado de coisas" ontológico. Ao invés disso, eles funcionam para camuflar a experiência da investigação e para manter misteriosos quaisquer compromissos ontológicos que se tenha. Como consequência, o uso dos termos "paradoxo" e "inefável" não fornecem dados para a comparabilidade, mas eliminam completamente a possibilidade lógica da comparabilidade da experiência. Considere o seguinte exemplo: (1) um místico A reivindica que a experiência "x" é paradoxal e inefável; enquanto (2) um místico B reivindica que a experiência “y” é paradoxal e inefável. A única conclusão lógica que se pode tirar nesta situação é que tanto o místico A quanto o místico B afirmam que sua experiência é paradoxal; nada pode ser dito sobre o conteúdo de suas respectivas experiências $\mathrm{x}$ e $\mathrm{y}$, pois não há como dar conteúdo às experiências $\mathrm{x}$ ou y de forma a aprender algo sobre elas, exceto, como já dissemos, pelo fato de ambas serem paradoxais, o que poderia então servir como base de uma comparação razoável. Assumir, como James, Huxley, Stace e muitos outros fazem, que, porque ambos os místicos afirmam que suas experiências são paradoxais, eles estão as descrevendo como experiências é uma non sequitur58.

Outra maneira de chegar a essa questão é fazendo a pergunta: "Que razão ontológica ou lógica exige que haja apenas uma experiência que é inefável ou paradoxal?” O que emerge em resposta a esta pergunta é que se a(s) experiência(s) mística(s) que está(ão) sendo descrita(s) com precisão quando se diz que é(são) paradoxal(is) e inefável(is), então esta(s) experiência(s) está(ão) sendo realmente removida(s) de toda possibilidade de definição, descrição, apontando também para a comparabilidade. Poder-se-ia expressar esta posição a respeito das reivindicações e consequências das reivindicações em relação à experiência mística desta forma: “Toda experiência mística 'x' é P e I, onde P = paradoxal e I = inefável”, portanto,

\footnotetext{
${ }^{58}$ NT - Non sequitur é uma expressão em língua latina (traduzida para português como "não se segue") que designa a falácia lógica na qual a conclusão não decorre das premissas. Em um non sequitur, a conclusão pode ser verdadeira ou falsa, mas o argumento é falacioso porque há falta de conexão entre a premissa inicial e a conclusão. Existem diversas variações de non sequitur, e outras falácias lógicas se originam dele, tais como a afirmação do consequente e a negação do antecedente.
} 
“qualquer afirmação a respeito do caráter interno de 'x' será paradoxal e inefável”. Dada esta posição, não há motivos razoáveis para fazer a afirmação de que duas experiências místicas x são iguais. Ou seja: no Caso (i), "x é PI” poderia logicamente se referir a uma experiência contendo atributos ou elementos a, b, c ...; enquanto no Caso (ii), "x é PI" poderia logicamente se referir a uma experiência contendo atributos ou elementos d, e, f. E o mesmo, em cada caso adicional, ou seja, Caso (iii), "x é PI" poderia logicamente se referir a uma experiência contendo atributos ou elementos g, h, k, e assim por diante. Como não há como se apoiar na expressão "x é PI" em cada caso respectivo, sendo esta de fato a força lógica da expressão "x é PI”, não há como avaliar os casos (i), (ii), (iii) a fim de verificar se eles são os mesmos - mesmo que fossem os mesmos. Uma vez introduzidas per definitionem as características do paradoxo e da inefabilidade, nenhum outro resultado pode se seguir. Além disso, não somente não há agora a possibilidade de comparar diferentes experiências místicas, mas também se abre a pergunta desconcertante sobre o status e a inteligibilidade dos outros elementos nos relatos místicos. Com que força qualquer dos elementos de um relato místico pode ser tomado como evidência de uma fenomenologia ou tipologia da mística, na medida em que essas afirmações estão associadas à noção básica de que a experiência mística é inefável e paradoxal? Se os termos "paradoxal" e "inefável" significam alguma coisa, eles não cancelam todas as outras reivindicações descritivas, minando assim toda e qualquer tentativa de uma tipologia fenomenológica da experiência mística baseada em relatos pós-experienciais? Há certamente algo logicamente e linguisticamente estranho no trabalho aqui que é quase sempre ignorado e que precisa de um exame crítico cuidadoso. A fortiori 59 parece que para que se leve a sério a reivindicação do místico, ou seja, que sua proposição "x é PI" seja uma descrição verdadeira, acaba por ter a implicação prejudicial de que não se pode fazer qualquer reivindicação razoável ou mesmo inteligível para qualquer proposição mística. A proposição “x é PI” tem o curioso resultado lógico de que uma interpretação séria da proposição não torna a experiência "x" inteligível nem

\footnotetext{
${ }^{59}$ NT - Indica que uma conclusão deverá ser necessariamente aceita, já que pela lógica ela é mais verdadeira que outra considerada como tal anteriormente. Um raciocínio é a fortiori quando contém certos enunciados que se supõem reforçarem a verdade da proposição que se tenta demonstrar. Traduz-se mais ou menos como "se aceitamos a verdade daquilo, então com muito mais razão temos de aceitar a verdade disto".
} 
nos informa de forma alguma sobre "x", mas antes cancela "x" de nossa linguagem - o que, é claro, é o que a maioria dos místicos afirma querer. Isso, entretanto, não é fundamento para uma fenomenologia da mística ou uma tipologia de experiência mística comparativa, pois há uma grande variedade de "estados de coisas" ontológicos mutuamente exclusivos que podem, portanto, ser descartados. Neste momento, trata-se genuinamente de um caso de "onde não se pode falar em silêncio"6o.

Dando um passo adiante, também deve ser observado que há uma questão complexa atuando na identificação do objeto da experiência mística e que é geralmente ignorada. Refiro-me ao fato de que os escritores que tratam da mística parecem tomar os termos "Deus", nirvāṇa etc., como meros nomes do que como descrições, ou seja, estes são tratados como se fossem rótulos arbitrários de alguma realidade comum subjacente. Isto, porém, é um erro, pois "Deus" e nirvāṇa ou mesmo "Ser" ou Urgrund61 não são apenas nomes ou, em primeira instância, descrições, ou pelo menos descrições disfarçadas, pois carregam em si um significado relativo a alguma estrutura ontológica. Assim, o termo "Deus" traz consigo características ontológicas, de perfeição, ou seja, todas as palavras onipresentes que atribuímos necessariamente a Deus, e características de "personalidade", etc. Alternativamente, ātman carrega também alguns dos mesmos sentidos, além de outras características ônticas, metafísicas e de "personalidade" consideravelmente diferentes e as mesmas, e mais radicalmente ainda, em alguns casos quando nos referimos ao nirvāṇa, totalmente opostas. A substituição do que parecem ser termos mais neutros como "Ser" também se mostra menos útil do que no início porque "Ser" também não é uma informação ontológica flutuante e livre, mas uma das partes soltas de um sistema de significados específicos. Quando Platão fala de "Ser", seu significado é diferente daquele pretendido quando o termo

\footnotetext{
${ }^{60}$ L. Wittgenstein; Tractatus Logico-philosophicus (Londres, 1961), seção 7. Sobre o tema da linguagem paradoxal em relatos místicos ver também W. Alston, "Inefabilidade" em Philosophical Review, 65 (1956); Paul Henle, "Mysticism and Semantics" em Philosophy and Phenomenological Research, v. iii (1949), p. 416-422; B. Russell, Mysticism and Logic (Londres, 1917); G. K. Pletcher, "Mysticism, Contradiction and Ineffability" em American Philosophical Quarterly, v. x (1973), p. 201-211; B. Williams, "Tertullian's Paradox" em A. Flew e A. Mclntyre (eds.), New Essays in Philosophical Theology (Nova York, 1955; Londres, 1972); "Mysticism and Sense Perception", Religious Studies. v. 9 (1975), p. 257-278; artigo de Peter Moore, "Mystical Experience, Mystical Doctrine, Mystical Technique" em Mysticism and Philosophical Analisys, p. 105-107; S. Katz, "The Language and Logic of Mystery" em S. Sykes e J. Clayton (eds.), Christ, Faith and History (Cambridge, 1972), p. 239-262; Richard Gale, "Mysticism and Philosophy" em The Journal of Philosophy, 57 (1960); J. N. Horsburgh, "The Claims of Religious Experience", The Australasian Journal of Philosophy, v. 35 (1957), p. 186-200.

${ }^{61}$ NT - Uma causa primordial ou princípio cósmico final.
} 
encontra seu caminho no vocabulário filosófico de Spinoza e Schelling, ou Sartre e Heidegger, para não falar de Zen ou Taoísmo.

Essas considerações nos levam novamente aos fundamentos da afirmação fundamental que está sendo apresentada neste artigo de que "a experiência mística é contextual”. Um lugar sugestivo para retomar o fio dessa discussão está no contexto da afirmação tão frequentemente feita e repetida de que a mística, em um ou outro sentido, visa ajudar o Eu a "transcender" sua condição. Assim, em todas as tradições, temos práticas que funcionam no papel da ascese como yoga, meditação e similares, que visam libertar o Eu de sua "existência condicionada", quaisquer que sejam as "condições" ideológicas experienciais, sócio-históricas e religiosas que possam acontecer. Esses processos de "libertação" aparecem, à primeira vista, como movimentos que levam o Eu dos estados de consciência "condicionada" à “incondicionada", da consciência "contextual” à "não contextual”. Além disso, esta é a forma usual de avaliá-los, especialmente por aqueles que buscam alguma variedade da filosofia perennis, como uma experiência mística comum universal. Para eles, por trás ou acima das limitações impostas à nossa consciência por nossa situação histórica, socioideológica condicionada, existe uma visão universal compartilhada da uniformidade da realidade, que é compartilhada por aqueles que sabem como transcender essas determinações sociológicas e históricas arbitrárias, sendo a evidência para isso a alegada similaridade da experiência mística entre culturas e épocas históricas. Aqueles que defendem essa posição, no entanto, são enganados pelas aparências. Pois é apenas na aparência que atividades como a yoga produzem o desejado estado de consciência "pura". Entendida corretamente, a yoga, por exemplo, não é um incondicionamento ou descondicionamento da consciência, mas sim um recondicionamento da consciência, ou seja, uma substituição de uma forma de consciência condicionada e/ou contextual por outra, embora uma forma nova, incomum e talvez totalmente mais interessante de consciência condicionada-contextual.

Não há nenhuma evidência substancial que sugira que exista uma consciência pura per si alcançada por estas várias práticas místicas comuns, como o jejum, a yoga e similares. Esse ponto pode ser bem ilustrado através da observação, da amplamente difundida prática da arte da yoga. É possível encontrar 
a yoga em todas as principais religiões orientais, mas o seu intuito, bem como o seu significado ${ }^{62}$, diferem de uma tradição para outra. Assim, por exemplo, no Hinduísmo Upanishad, a yoga é praticada a fim de purificar e unificar a "alma" individual e depois uni-la com Brahman ou, como mais tarde representado no Bhagavad Gita, com Krishna. Entretanto, mesmo dentro do Hinduísmo, a yoga combina com outros sistemas metafísicos que afirmam fornecer o "caminho" e definir o "objetivo", samādhi, de forma diferente. A tradição Sāṃkhya, por exemplo, entende que o objetivo é a perfeição da alma que não leva a qualquer forma de união mística, mas sim a uma esplêndida autoidentidade que, como a perfeição de Deus, é autocontida e isolada63. Alternativamente, o Budismo também herdou as práticas de yoga como um elemento central, mas agora como central para um esquema metafísico radicalmente diferente que não reconhecia nem a existência de um Deus pessoal - ou mesmo impessoal - nem a substancialidade de almas individuais (ātman ou perusha). Ao invés disso, o Budismo vê a yoga como uma técnica para superar sua razão de ser (raison d'étre) metafísica, o sofrimento e a libertação corolária de todas as ilusões de substancialidade. A yoga é então agora colocada a serviço do "vazio", lembrando que o vazio não é um “algo" e que não se deve reificar o vazio em uma coisa como, por exemplo, Heidegger faz com o "nada"64. Deve-se notar também que no Budismo, assim como no Hinduísmo, a própria metafísica se tornou objeto de debate e cisma, criando escolas budistas alternativas $^{65}$ com suas diferentes análises da natureza e propósito da yoga. Sem entrar em maiores detalhes, basta observar que a yoga é também praticada no Jainismo e em outras tradições orientais que levam ainda a outras visões além daquelas encontradas no Hinduísmo ou no Budismo em relação à natureza da alma, à realidade última e ao propósito da vida. Essa variedade de crenças doutrinárias dogmáticas não é algo a ser descartado como meramente marginal ou

\footnotetext{
${ }^{62}$ Sobre a grande variedade de possíveis significados do termo "yoga", ver, por exemplo, E. W. Hopkins, "Yoga technique in the Great Epic [Mahabharata]" in JAOS, v. xxii (1901), p. 333-379. Ver também o estudo exaustivo da yoga de Mircea Eliade, Yoga (Londres, 1958; New Jersey, 1969 2); e J. H. Wood, The Yoga-system of Pantanjali (Cambridge, Mass., 1914).

${ }^{63}$ Para mais informações, ver R. C. Zaehner, Hinduism (Nova York, 1962; Oxford, 1966), p. 94 e seguintes.

${ }^{64}$ Ver, por exemplo, F. Streng, Emptiness (Nashville, 1967); ver também R. Robinson, The Buddhist Religion, p. 52-53. Sobre algumas das questões lógicas levantadas por este tópico, ver S. Katz, "The Logic and Language of Mystery" em S. Sykes e J. Clayton (eds.), Christ, Faith and History (Cambridge, 1972), p. 239-262.

${ }^{65}$ Ver C. Prebish (ed.). Buddhism: A Modern Perspective; ver também David Kalupahana, Buddhist Philosophy (Havaí, 1976), especialmente o cap. 12; M. Eliade, Yoga (Londres, 1958; Nova Jersey, 19692); T. Nanaponika, The Heart of Buddhist Meditation (Nova York, 1962).
} 
preparatório, nem se pode, reconhecendo a complexidade das circunstâncias, falar da yoga em abstrato, pois, nessa circunstância, certamente ela se tornará apenas uma abstração vazia. Além disso, o elemento contextual torna-se ainda mais importante quando se percebe que para os sistemas indianos a metafísica é a soteriologia. O que se acredita que afete a salvação de alguém - "salvação" esta, diferentemente entendida de tradição para tradição, segundo o(s) respectivo(s) objetivo(s) de cada uma. A experiência que o místico ou yogi tem é a que ele busca como consequência das crenças compartilhadas que mantém através de seus compromissos doutrinários metafísicos.

Intimamente aliada à alegação equivocada de que podemos alcançar um estado de consciência pura é a noção frequentemente usada de "dádiva66" ou da "talidade" ou do "real" para descrever o estado puro da experiência mística que transcende toda coloração epistemológica contextual. Mas que sentido têm esses termos? O que é o "dádiva", "talidade" ou mesmo o "real”67? A análise desses termos indica sua relatividade; eles são aplicados a uma variedade de "estados de coisas" alternativos e até mesmo mutuamente exclusivos e "estados de coisa nenhuma". Essa variedade em si deve nos alertar sobre o perigo real e a arbitrariedade envolvida nesse esquema. Os fenomenólogos parecem especialmente propensos a esta ingenuidade infrutífera - todos intuem a "dádiva", mas suas intuições diferem significativamente. Pode-se dizer com justiça que nenhuma tentativa de afirmar claramente ou individualizar o que é "dádiva" foi bem sucedida. De fato, falar de "dádiva" parece ser um movimento feito para provocar um curto-circuito no próprio tipo de investigação epistemológica que está sendo feita aqui, mas, tal movimento falha porque não há evidência de que haja qualquer "dádiva" que possa ser revelada sem a imposição das condições mediadoras do conhecedor. Todas as "dádivas" são também o produto dos processos de "escolha", "modelagem" e "recebimento". Ou seja, a "dádiva" é apropriada através de atos que a modelam em formas que possamos tornar inteligíveis para nós mesmos dada nossa constituição conceitual, e que a

\footnotetext{
${ }^{66}$ NT - No original o autor usa a palavra given que deveria ser traduzida como "dado", mas que perde o sentido. Aqui temos o sentido de algo que foi concedido, uma "graça". Entendemos, portanto, que "dádiva" expressa melhor essa ideia.

${ }^{67}$ Para uma discussão interessante de vários sentidos do termo "real", ver J. Bennett, "Real" em K. T. Fann (ed.), Symposium on J. L. Austin (Londres, 1969), p. 267-283.
} 
estruturem para responder às necessidades contextuais específicas e mecanismos de consciência do receptor. Esta descrição da atividade epistêmica, mesmo a atividade epistêmica envolvida na experiência mística, obviamente requer o que na língua kantiana, embora não à maneira de Kant, seria chamada de “dedução transcendental"68, ou seja, um argumento que revela tanto as condições de conhecimento em geral quanto os fundamentos de seu próprio funcionamento e que é tematizado de acordo com possibilidades específicas - e isso parece tanto apropriado quanto necessário, embora sua estrutura não possa sequer ser delineada aqui. Não parece haver outra maneira de chegar a uma questão que seja filosoficamente satisfatória e que satisfaça nosso interesse na legitimação das condições de conhecimento, incluindo o conhecimento místico. Isto significa que o místico, mesmo em seu estado de consciência recondicionada, também é um modelador de sua experiência; que ele não é uma tábula rasa na qual a "plenitude"69 ou a "dádiva" simplesmente se impõe - seja qual for a plenitude que ele esteja buscando e encontre. Isto é muito certo: a experiência mística deve ser mediada pelo tipo de seres que somos. E o tipo de seres que somos exige que a experiência não seja apenas instantânea e descontinuada, mas que envolva também memória, apreensão, expectativa, linguagem, acumulação de experiência anterior, conceitos e expectativas, com cada experiência sendo construída sobre o legado de todos esses elementos, sendo moldada de novo por cada nova experiência. Assim, a experiência de $\mathrm{x}$ - seja x Deus ou nirvāṇa - é condicionada tanto linguística como cognitivamente por uma variedade de fatores, incluindo a expectativa do que será experimentado. Relacionadas a essas expectativas estão também atividades futuras dirigidas, tais como meditação, jejum, abluções rituais, automortificação etc., que criam expectativas adicionais sobre como serão o futuro e os estados futuros de

\footnotetext{
${ }^{68}$ Kant definiu o conhecimento transcendental da seguinte forma: “Chamo de transcendental todo conhecimento que está preocupado não tanto com objetos, mas com o modo do nosso conhecimento dos objetos em geral, na medida em que este modo de conhecimento seja possível a priori." Critique of Pure Reason, B25. Ver também de Kant Critique of Judgement, "Introduction". Sobre a discussão contemporânea do que está envolvido na tentativa de enquadrar uma tal "dedução transcendental", ver a obra de W. van O. Quine's, Word and Object (Cambridge. Mass., 1960), bem como sua obra Ontological Relativity adn Other Essays (Nova York, 1969). Ver também P. F. Strawson, Individuals (Londres, 1959) e sua obra Bounds of Sense (Londres, 1966). Da literatura recente, veja M. S. Gram, "Transcendental Arguments", Nous 5 (1971), p. 5-26; e Gram novamente em: "Hintikka and Spurious Transcendentalism" em Nous 8 (1974); "Categories and Transcendental Arguments", em Man and World 6 (1973); "Must Transcendental Arguments be Spurious?" em Kant-Studien 65 (1974). Ver também J. Hintikka, "Transcendental Arguments" em Nous 6 (1972), p. 274-281. As edições posteriores de Kant-Studien têm muitos outros documentos de interesse e relevância sobre este tema, demasiadamente numerosos para serem listados separadamente aqui.

${ }^{69}$ NT - A palavra usada originalmente pelo autor foi ultimate que poderia ser traduzida por "final", "completude". Aqui tem sentido de algo que finaliza as buscas do ser, por isso "plenitude".
} 
consciência. Há obviamente um aspecto profético autorrealizável para esse tipo de atividade.

O papel criativo do Eu na sua experiência não é análogo ao papel passivo de um gravador de fita ou de uma câmera. Mesmo na experiência mística, parece haver atividade epistemológica do tipo que conhecemos como discriminação e integração e, em certos casos, pelo menos, outras atividades mentais como a de relacionar a experiência presente com a experiência passada e futura, bem como reivindicações teológicas tradicionais e metafísicas. Tomemos, por exemplo, as descrições de Jan van Ruysbroeck dadas em sua obra O Ornamento do Casamento Espiritual (The Adornment of the Spiritual Marriage):

Quando o homem interior e observador de Deus alcançou assim sua Imagem eterna, e nesta clareza, através do Filho, entrou no seio do Pai: ele é então iluminado pela verdade Divina, e ele recebe de novo, a cada momento, o Nascimento Eterno, e vai em frente de acordo com o caminho da luz em uma contemplação Divina. E aqui começa o quarto e último ponto, ou seja, um encontro amoroso, no qual, acima de tudo, consiste nossa mais alta bem-aventurança.

Você deve saber que o Pai celestial, como terra viva, com tudo o que vive Nele, está ativamente voltado para Seu Filho, como para Sua própria Sabedoria Eterna. E essa mesma Sabedoria, com tudo o que vive Nele, está ativamente voltada para o Pai, ou seja, para aquele mesmo terreno do qual Ele sai. E neste encontro, surge a terceira Pessoa, entre o Pai e o Filho; ou seja, o Espírito Santo, Seu Amor mútuo, que é um só com eles. Ambos na mesma natureza. E envolve e embebe tanto em ação e fruição o Pai e o Filho, e tudo o que vive em ambos, com tanta riqueza e tanta alegria que, quanto a isto, todas as criaturas devem ficar eternamente em silêncio; pois a incompreensível maravilha deste amor eternamente transcende a compreensão de todas as criaturas. A maravilha é compreendida e saboreada sem espanto, ali o espírito habita acima de si mesmo, e em um com o Espírito de Deus; e saboreia e vê sem medida, mesmo como Deus, as riquezas que são o próprio espírito na unidade do solo vivo, onde ele se possui de acordo com o caminho de sua essência não criada.

Agora este encontro arrebatador é incessante e ativamente renovado em nós, segundo o caminho de Deus; pois o Pai se dá no Filho, e o Filho se dá no Pai, num conteúdo eterno e num abraço amoroso; e isto se renova a cada momento dentro dos laços do amor. Pois assim como o Pai contempla incessantemente todas as coisas no nascimento de Seu Filho, assim também todas as coisas são amadas de novo pelo Pai e pelo Filho na efusão do Espírito Santo. E este é o encontro ativo do Pai e do Filho, no qual somos abraçados com amor pelo Espírito Santo no amor eterno. (RUYSBROECK, 1916, p. 176). 


\section{Ruysbroeck passa então a descrever a "unidade" que o homem pode alcançar}

em Deus, que cito na íntegra:

Depois disso, segue-se a união sem distinção. Pois é preciso apreender o Amor de Deus não apenas como uma efusão com todo o bem, e como um retorno à Unidade; mas é também, acima de tudo, uma distinção, uma fruição essencial na Essência pura da Divindade. E em consequência disso, os homens esclarecidos encontraram dentro de si uma contemplação essencial que está acima da razão e sem motivo, e uma tendência frutificante que penetra em toda condição e todo ser, e através da qual mergulham em um abismo insondável de bem-aventurança, onde a Trindade das Pessoas Divinas possui sua Natureza na Unidade essencial. Eis que esta bem-aventurança é tão profunda e tão desimpedida que nela cessam todos os olhares essenciais, as tendências e a distinção criadora, que passam. Pois, por esta fruição, todos os espíritos elevados são mesclados e saciados na Essência de Deus, que é a superessência de toda essência. Lá eles caem de si mesmos numa solidão e numa ignorância insondável; ali toda a luz se transforma em trevas; ali as três Pessoas dão lugar à Unidade Essencial, e permanecem sem distinção na fruição da bem-aventurança essencial. Esta bem-aventurança é essencial a Deus, e superessencial a todas as criaturas; pois nenhuma essência criada pode se tornar uma só com a Essência de Deus e passar longe de sua própria substância. Pois assim, a criatura se tornaria Deus, o que é impossível; pois a Essência Divina não pode se tornar um só com a Essência de Deus, nem pode ser acrescentada a ela ou tirada dela. No entanto, todos os espíritos amorosos são uma fruição e uma bem-aventurança com Deus sem distinção; pois esse estado beatificante, que é a fruição de Deus e de todos os Seus amados, é tão simples e contínuo que nem o Pai, nem o Filho, nem o Espírito Santo são distintos de acordo com as Pessoas, nem nenhuma criatura. Mas todos os espíritos iluminados estão aqui elevados acima de si mesmos em uma fruição sem caminho, que é uma abundância além de toda a plenitude que qualquer criatura alguma vez recebeu ou jamais receberá. Pois ali todos os Espíritos elevados são, em sua superessência, uma fruição e uma bem-aventurança com Deus, sem distinção; e ali esta bem-aventurança é tão contínua que nenhuma distinção pode entrar nela. E isto foi pedido por Cristo quando Ele suplicou a Seu Pai no céu que todos os seus amados se tornassem perfeitos em um só, assim como Ele é um com o Pai através do Espírito Santo... (RUYSBROECK, 1916, p. 245).

Embora esta descrição possa aparecer, em uma primeira leitura, epistemologicamente, teologicamente ou metafisicamente neutra, uma inspeção mais detalhada revelará uma miríade de suposições dessa ordem ou de doutrinas que colorem o relato tanto antes quanto depois de sua ocorrência.

Além disso, em quase todos os casos, senão em todos eles, a experiência mística sabe, como já demonstramos, qual o fim que busca desde o início de sua travessia pelo "caminho do místico". Assim, o tariq sufi, o Tao do taoísta, o dharma budista e a via mística cristã são todos "intencionais", ou seja, pretendem 
algum estado final de ser ou não ser, algum objetivo de união ou comunhão, algum senso de libertação, exaltação, bem-aventurança ou alegria. E o tariq, o Tao, e a via mística buscam objetivos diferentes porque seus problemas iniciais, generativos, são diferentes. Os místicos sufi e cristãos começam com os "problemas" da finitude, do pecado e da distância de Deus, enquanto o budista começa com o problema do sofrimento e anitya ou impermanência e, novamente, o taoísta parte de uma apreciação positiva do Eu e do mundo e procura prolongar a vida espiritual pela vitória do yang sobre o yen. Os respectivos problemas "geradores" no coração de cada tradição sugerem suas respectivas respostas alternativas envolvendo, como fazem, diferentes construções mentais e epistemológicas, compromissos ontológicos e superestruturas metafísicas que ordenam as experiências de diferentes maneiras. A mente pode ser vista como elemento de contribuição tanto para o problema quanto para os meios de sua superação: ela define a origem, o caminho e o objetivo, moldando-a em conformidade com a experiência. A experiência do nirvāna budista, do devekuth judaico, de unio mystica do cristão, de fana do sufista, e de Tao do taoísta, são o resultado, pelo menos em parte, de influências conceituais específicas, ou seja, os "problemas iniciais" de cada sistema doutrinário, teológico. Cada um de nós é uma consciência unitária e cada um de nós conecta o "problema" e sua "resposta" através de formas de conexão, síntese e objetividade que são parte integrante de nossa consciência como agentes conscientes do tipo que somos. De fato, parece que os diferentes estados de experiência, que se chamam nirvāṇa, devekuth, fana etc., não são o terreno, mas o resultado da complexa atividade epistemológica que é posta em movimento pelo caráter integrador da autoconsciência empregada na modalidade especificamente mística. Essas operações sintéticas da mente são de fato as condições fundamentais sob as quais, e somente sob as quais, a experiência mística, como toda experiência, se realiza. Essas condições construtivas de consciência produzem os fundamentos sobre os quais essa experiência é possível em absoluto.

Toda essa área da "intencionalidade" da experiência e da linguagem da experiência no que se refere à mística é rica para o estudo posterior. Somente para introduzir o significado deste tópico para nossas inquietações, vou sugerir apenas que, se olharmos atentamente a linguagem dos místicos, bem como a devoção 
mística, práticas e literatura, descobriremos que muito disso é "intencional" no sentido sugerido por Husserl e Brentano. Embora eu não seja grande admirador de nenhum dos dois em relação às suas posições metafísicas mais gerais, sua discussão sobre a "linguagem intencional" são em si instrutivas, pois chamam nossa atenção para certos termos como "expectativas", "crenças", "esperanças", "buscas", “investigações", “desejos”, "necessidades", “encontros", "procuras", envolvem, como Brentano disse, "um objeto em si mesmas". Devemos prestar atenção ao alerta de que a intencionalidade linguística não gera ou garante a existência do "objeto intencional", mas devemos também reconhecer o caráter epistemologicamente formativo da linguagem intencional que se espelha como um ato intencional de consciência. Usando a linguagem que os fenomenólogos modernos privilegiam, podemos dizer que "intencionalidade" significa descrever um "dado como significado", ou seja, estar ciente de que uma ação inclui um alcance para algum significado específico ou conteúdo significativo.

A importância do reconhecimento da qualidade intencional de grande parte da teoria e prática mística pode ser trazida à tona pela reflexão sobre a intencionalidade envolvida na yoga como comportamento místico. Dessa forma, basta fazer ao místico a pergunta muito pertinente: "Por que você está fazendo isso ou aquilo?” A esta pergunta, o yogi, por exemplo, responderá que ele emprega sua prática exaustiva porque se prende a uma metafísica específica de si mesmo e de sua dor (diferente no Hinduísmo e no Budismo e até mesmo dentro de cada grande tradição) e acredita que, nas palavras da Śiva Samhitā (apud ELIADE, 1958, p.40): "Através da prática [da yoga] se obtém o sucesso (abhyasa), através da prática se ganha a libertação." O místico sufista responderia da mesma forma que pratica os atos rituais do dhikr (recordação dos nomes divinos), os exercícios respiratórios, o jejum e os regimes de oração porque, como observa Ibn Ata Allah (apud TRIMINGHAM, 1971, p. 198): “A recordação de Deus (dhikr)... é o próprio suporte sobre o qual repousa o Caminho (tariqa) (para a unidade com Deus, ou seja, tawhid).”. O mesmo tipo de respostas e raciocínios intencionais (embora naturalmente dando diferentes intenções) podem ser encontrados na maioria das tradições místicas, e certamente nas do Judaísmo, Cristianismo, Islamismo, Budismo, Taoísmo e Hinduísmo. 
Embora tenhamos nos concentrado em grande parte deste trabalho no papel ativo do autoconhecimento no processo epistemológico como uma correção à forma tradicional de abordagem da experiência mística, também é preciso reconhecer, ao mesmo tempo, que essa situação experiencial também precisa ser revista. Ou seja, para que meus leitores não tenham uma compreensão equivocada de minha visão, ou da complexidade do processo epistemológico envolvido na experiência mística, são necessárias algumas palavras sobre o aspecto "conhecido" da experiência mística. Para que as condições da experiência mística sejam estabelecidas corretamente e em perspectiva adequada, é imperativo notar que em qualquer situação experiencial como aquela reivindicada pelos e para os místicos, o conteúdo completo do conceito de experiência precisa ser apreciado. Quando uma pessoa diz, "eu experimento $x$ ", ele não só está envolvido nos tipos de procedimentos epistemológicos que acabamos de discutir, ou seja, que a sua mente está ativa na construção de x como algo experimentado, mas ele também está afirmando que há um x a ser experienciado. Em outras palavras, os místicos e estudantes da mística têm que reconhecer que a experiência mística não é (putativamente) apenas o produto do ato de experiência condicionada como constituída do lado do daquele que a experimenta, mas também é constituída e condicionada pelo que o objeto ou "estado de coisas" são, e o que o místico (acredita), "encontra" ou experimenta. Dizer que "uma pessoa experimenta x" é também reconhecer que tal experiência depende em parte do que é x. Mas aqui está a questão: esse reconhecimento também requer a consciência adicional da complexidade da situação, na medida em que o que "x é", é em si mesmo, ou pelo menos em parte, determinado por uma consciência contextual. Para esclarecer esse ponto, considere o seguinte exemplo: dizer que, "uma pessoa tem uma experiência mística de Deus" significa, em termos de nossa discussão anterior, não apenas afirmar que essa pessoa condiciona a situação de maneira estruturada, mas também que a constituição de sua experiência depende do conhecimento da suposta realidade do objeto de sua experiência, ou seja, Deus. No entanto, a complexidade é agravada pelo reconhecimento de que a própria existência de "Deus" contribui, pelo menos em parte, para a experiência. Poder-se-ia expressar essa dialética mais claramente como se segue: "Uma pessoa experimenta Deus" 
implica, dado o forte senso de experiência que os místicos pretendem, tanto (a) "Uma pessoa conscientemente constitui 'Deus", assim como (b) "Deus' se faz conhecido para essa pessoa" - reconhecendo que aqui "Deus" também foi, pelo menos parcialmente, condicionado por essa pessoa. Essa pessoa, como todos nós, só conhece as coisas como elas "aparecem" para ela.

Uma outra forma de revelar esses diferentes elementos na experiência mística (e em outra) é reconhecer o que a linguagem tem que nos ensinar através do uso das duas locuções bem diferentes: (a) "Uma pessoa experimenta Deus" e (b) "Deus é dado a essa pessoa na experiência". A locução (a) sugere algo do reconhecimento da independência do objeto da experiência, embora esta também seja regulada por estruturas de consciência e experiência, enquanto a locução (b) aponta em direção à situação, ou seja, o fato de que nossa experiência de Deus pertence a um contexto experiencial que é, pelo menos parcialmente, regulador e determinante do conteúdo da experiência. Dessa forma, podemos novamente ver claramente como é que as experiências místicas diferem de tradição para tradição. O místico judeu "experimenta Deus" e "Deus é dado ao judeu em sua experiência", enquanto o místico budista, em contradição, reconhece a "objetividade" do nirvāṇa e ambos "experimentam nirvāṇa" e tem "nirvāṇa dado a ele" (se faz presente) em sua experiência. Além disso, levar em conta os diferentes objetos de experiência é reconhecer a necessidade da diferença das próprias experiências - mesmo que tais diferenças tenham elas próprias, pelo menos parcialmente, contribuído para a "realidade" em um estágio anterior ou paralelo.

\section{PARTE IV}

Nossa discussão, embora um pouco longa, só começou a tocar em algumas das questões mais fundamentais relacionadas a um estudo filosófico e fenomenológico adequado da mística. Nosso principal objetivo tem sido marcar uma nova maneira de abordar os dados, concentrando-nos especialmente em dissuadir os pesquisadores da noção preconcebida de que toda experiência mística é a mesma ou similar. Se a experiência mística é sempre a mesma ou similar em 
essência, como é tão frequentemente afirmado, então isso tem que ser demonstrado por recurso e manuseio preciso de evidências, argumento lógico convincente e procedimentos epistemológicos coerentes. Essa posição não pode ser sustentada meramente através de afirmações, por mais apaixonadas e avançadas que estas sejam, nem pode ser novamente demonstrada através de suposições $a$ priori sobre o assunto que "provem" seu caso em um círculo fechado.

Espero que tenha ficado claro que não sustentamos nenhuma tradição mística para sermos superiores ou "normativos" como, por exemplo, fizeram Stace e Zaehner (e em direções opostas, pode-se acrescentar, Stace favorecendo o monismo e Zaehner o teísmo). Nem temos tampouco uma posição dogmática particular a defender nessa discussão. Nossa única preocupação tem sido a de tentar ver, reconhecendo o contexto de nosso próprio entendimento, o que as evidências místicas permitirão no caminho da legítima reflexão filosófica. Nossa investigação sugere o que ela sugere - uma grande variedade de experiências místicas que são, pelo menos em relação a alguns aspectos determinantes, cultural e ideologicamente fundamentadas. No entanto, tendo defendido esta posição, estamos cientes de que duas coisas têm que continuar a ser feitas: (1) deve ser empreendido um estudo mais cuidadoso, especializado, das tradições místicas específicas com o fim de descobrir quais são suas características e especialmente como elas se relacionam com o meio teológico maior do qual emergem; e (2) devem ser empreendidas outras pesquisas epistemológicas fundamentais sobre as condições da experiência mística a fim de pôr a nu o esqueleto de tal experiência, na medida do possível. Este último empreendimento é especialmente importante e, ainda assim, é ainda mais negligenciado.

Uma palavra final sobre o uso das evidências disponíveis e a construção de uma teoria para explicar isso. Um forte elemento de apoio em favor de nossa narrativa pluralista é o fato de nossa posição ser capaz de acomodar todas as evidências que são contabilizadas pelas demonstrações não pluralistas, sem ser reducionista, ou seja, é capaz de fazer mais justiça à especificidade das evidências e suas distinções e disjunções inerentes do que as abordagens alternativas. Portanto, nosso relato (a) não ignora nenhuma evidência, (b) nem tem nenhuma necessidade de simplificar a evidência disponível para torná-la adequada a categorias 
comparativas ou análogas, (c) nem começa com suposições a priori sobre a natureza da realidade final - qualquer que seja a forma teológica tradicional particular que esta suposição metafísica tome (tais suposições a priori são comuns a quase todas as narrativas não pluralistas). Como consequência dessas vantagens hermenêuticas, é possível respeitar a riqueza dos dados experimentais e conceituais envolvidos nesta área de preocupação: "Deus" pode ser "Deus", "Brahman" pode ser "Brahman" e nirvāṇa pode ser nirvāṇa sem qualquer tentativa reducionista de equiparar o conceito "Deus" ao de "Brahma", ou "Brahman" ao de nirvāṇa. Esse respeito pela evidência relevante, tanto experimental quanto conceitual, é um elemento essencial no estudo da mística que é desconsiderado apenas por risco do filósofo.

\section{REFERÊNCIAS}

BUBER, Martin. I and thou. Nova York: Charles Scribner's Sons, 1970.

ECKHART, Meister. Mystische schriften. Berlin: Landauer, 1903.

ELIADE, Mircea. Yoga. Londres: Bollingen Foundation Inc, 1958.

JAMES, William. The varieties of religious experience. Nova York: Longmans, 1958.

NICHOLSON, Reynold A. The mystics of Islam. Londres: G. Bell and Sons, 1914.

PREBISH, Charles S. Buddhism: a modern perspective. Pennsylvania: The Pennsylvania State University, 1975.

ROBINSON, Richard. The Buddhist religion. Califórnia: Dickenson, 1970.

RUYSBROECK, Jan van. The adornment of the spiritual marriage. Londres: J. M. Dent \& Sons, 1916.

STACE, W. T. Mysticism and philosophy. Londres: Macmillan \& Co Ltd, 1961.

TRIMINGHAM, J. S. Sufi orders. Oxford: Clarendon Press, 1971.

UNDERHILL, Evelyn. Mysticism. Londres: Metthuem \& Co, 1911.

WITTGENSTEIN, Ludwig. Philosophical investigations. Oxford: Basil Blackwell \& Mott, 1958.

ZAEHNER, R. C. Concordant discord. Oxford: Clarendon Press, 1970. 